\title{
Q3/Q4 2018 Solar Industry Update
}

David Feldman, NREL Anna Ebers, DOE Robert Margolis, NREL January 2019

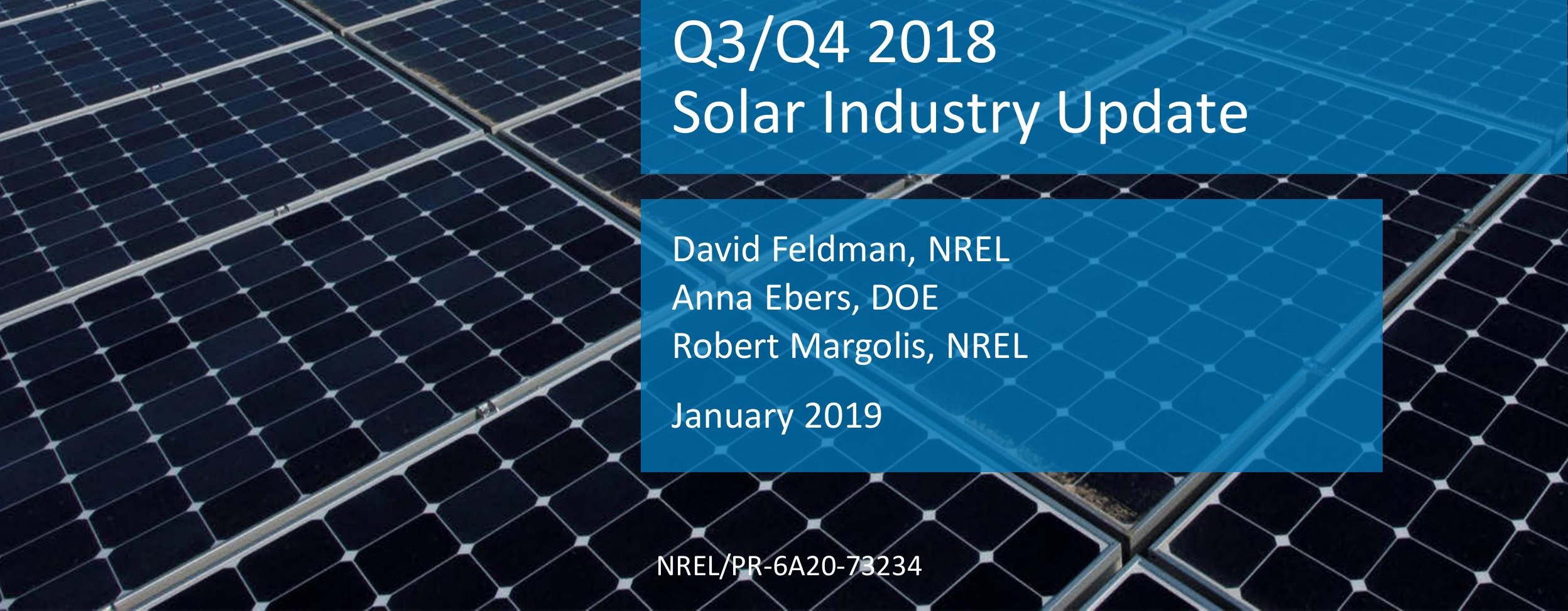




\section{Executive Summary}

- By the end of 2018, Hawaii, California, the District of Columbia, 104 cities, 11 counties, and 51 American companies in the United States had made $100 \%$ clean power commitments.

- In 2018, renewables generated more electricity (41\%) in Germany than coal (38\%) - a first.

- An IEA report projects $4.3 \mathrm{GW}-\mathrm{AC}$ of global CSP installations from 2018 to 2023.

- EIA estimates $23 \%$ of all new electricity generating capacity in the United States came from solar installations in 2018-second to natural gas.

- Utility-scale PV contributed 39\% to Q3 2018 U.S. PV installations-its lowest level since Q1 2012. Wood Mackenzie attributes the low level of utility-scale PV installation to uncertainty of the impacts of the Section 201 tariff in 2017.

- In January 2019, the California IOU PG\&E declared bankruptcy; it is uncertain how this development might impact utility-scale solar PPAs signed within the past several years.

- Roughly $3 \mathrm{GW}$ of new or refurbished U.S. PV manufacturing capacity is expected to come online in 2019. Historically, actual production capacity brought online has often taken longer and/or been lower than originally reported.

- In January 2019, global module ASP was reported to be $\$ 0.22 / \mathrm{W}$.

- In 2018 , solar stocks were down $28 \%$ compared to $-1 \%$ performance by the S\&P 500 Index.

- 2018 global and U.S. solar investment were \$132B and \$21B respectively - the vast majority of which went to project deployment.

A list of acronyms and abbreviations is available at the end of the presentation. 
1 State and Federal Updates

2 Global Solar Deployment

3 U.S. PV Deployment

4 PV System Pricing

5 Global Manufacturing

6 Component Pricing

7 Market Activity 
1 State and Federal Updates

\section{Global Solar Deployment}

3 U.S. PV Deployment

4 PV System Pricing

5 Global Manufacturing

6 Component Pricing

7 Market Activity
By the end of 2018, Hawaii, California, the District of Columbia, 104 cities, 11 counties, and 51 American companies all over the United States made commitments to $100 \%$ clean power. 

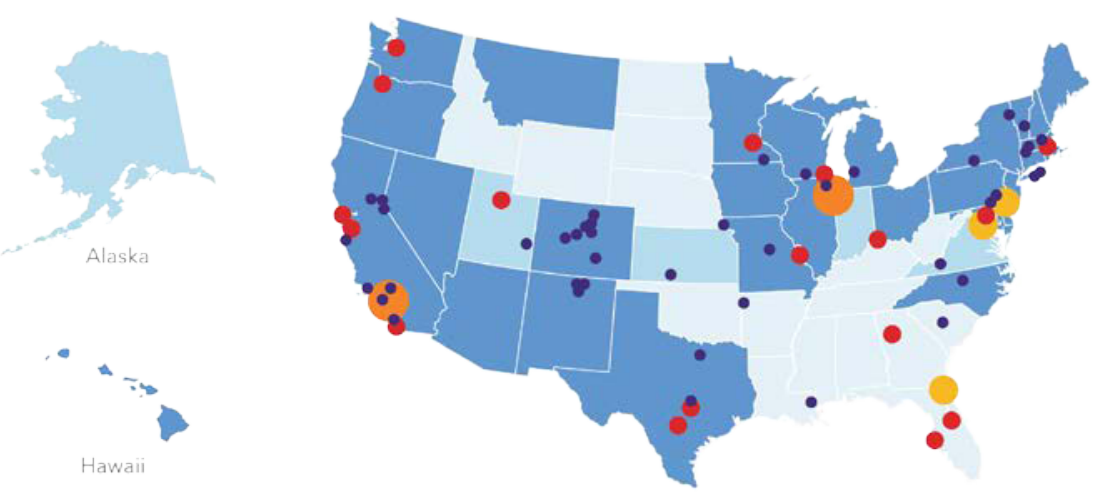

Renewable Portfolio Standards and Goals

Renewable Portfolio Standard (Binding)

Renewable Portfolio Goal (Voluntary)

No RPS or Goa

Goals range from $12.5 \%$ in Ohio and North Carolina to $100 \%$ in several states, territories, counties, and cities.
- 0.0-2.7 TWh $7.4 \cdot 16.8 \mathrm{TWh}$

2.7.7.4 TWh $16.8 \cdot 33.0 \mathrm{TWh}$
- Non-federal U.S. actors have increased efforts for clean energy deployment.

- A recent report titled America's Pledge estimates clean energy commitments by states, cities, and businesses could increase demand for non-hydro renewable energy generation to 500 TWh by 2025-enough to power 56 million homes for a year.

- While the technical feasibility for $100 \%$ renewable electricity is currently being debated by the scientific community, many policymakers and corporate leaders have pushed for aggressive clean energy targets, including some with $100 \%$. 


\section{Cities with $100 \%$ Clean Electricity Commitments}

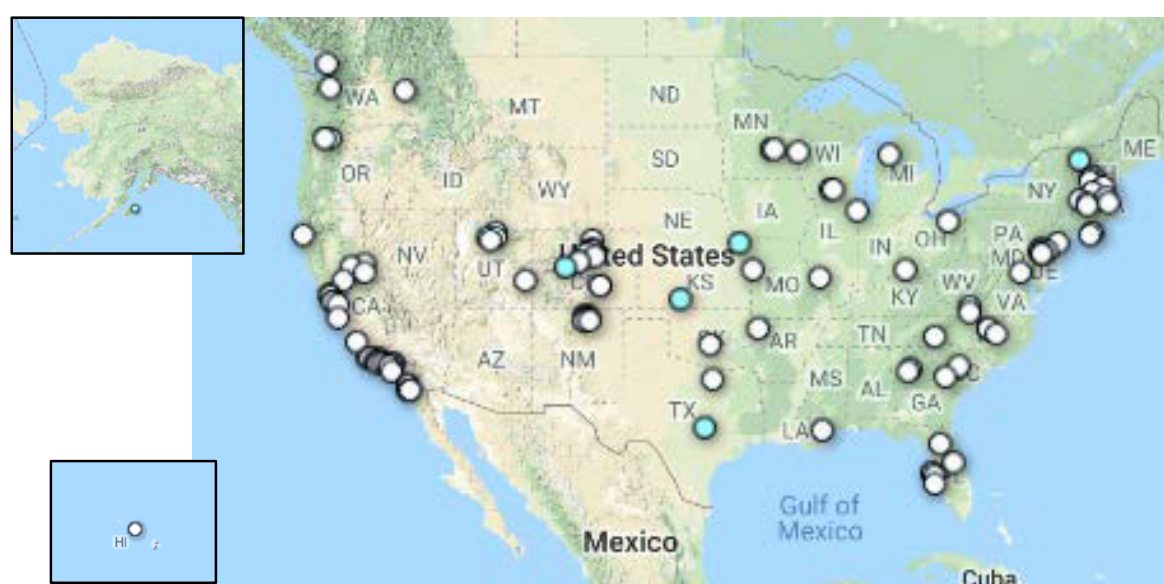

Powered by $100 \%$ Renewable Energy: These communities have currently achieved their $100 \%$ clean, renewable electricity targets.

Committed to $100 \%$ Renewable Energy: These communities have made community-wide commitments to transition to $100 \%$ clean, renewable electricity by no later than 2050.
- By the end of 2018, 104 cities and 11 counties all over the United States had made $100 \%$ clean power commitments.

- Fifty million people, or over $15 \%$ of the U.S. population, now live in these places.

- Notable clean energy commitment announcements in 2018 include a number of major cities, including Minneapolis, Cincinnati, Denver, and Berkeley.

- Six cities have already achieved their $100 \%$ clean power targets.

- Most commitments have a target date between 2030 and 2050. 


\section{States' Commitments to $100 \%$ Clean Electricity}

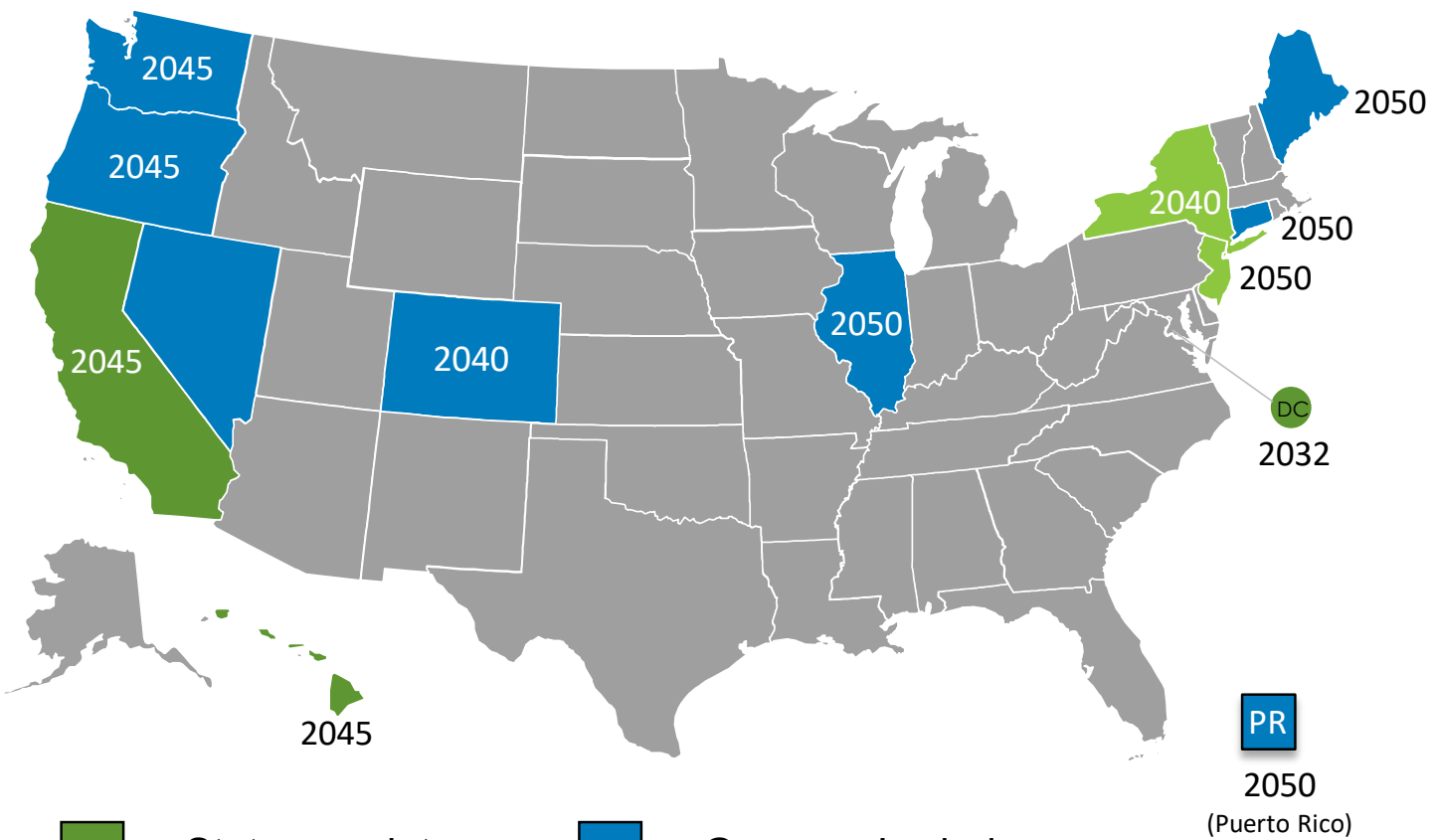

State mandate Executive order
- In 2018, California and Washington, D.C. joined Hawaii in committing to $100 \%$ clean power.

- Additionally, the governors of New Jersey and New York signed executive orders, and eight governors made pledges (CO, CT, IL, MA, ME, OR, PR, and WA) to achieve $100 \%$ clean electricity.

- In 2017, these 13 jurisdictions consumed more than $18 \%$ of U.S. electricity.

- All these commitments have a target date between 2030 and 2050. 


\section{Private Sector Commitments to $100 \%$ Renewable Energy}

- Companies have also made similar commitments to $100 \%$ renewable energy.

- With 158 members globally, the non-profit RE100 commits businesses to $100 \%$ renewable power for their global operations.

- Last year, 10 new American companies joined the RE100 initiative, increasing the number of American companies to 51.

- Currently, these U.S. businesses consume over 29 million MWh of electricity per year, $56 \%$ of which is currently supplied from renewable sources.

- The United States is the most represented country in the RE100.

- A large share of RE100 companies operate in the banking and consumer sectors.

- To achieve $100 \%$ renewable energy, U.S. companies in most cases opt to purchase unbundled RECs or sign a PPA. Self-generation is still not widely practiced.
- A 2018 survey found business executives believe that committing to renewable energy targets strengthened their brand reputation.

- Outside the RE100 project, businesses were making similar pledges.

- Sony committed to achieving $100 \%$ renewable energy for its North American operations.

- Xcel was the first utility to announce it will be carbon-free by 2050.

- In 2017 , they were the provider for $55 \%$ and $47 \%$ of the customers in Colorado and Minnesota respectively. They also provide service in Michigan, New Mexico, North Dakota, South Dakota, Texas, and Wisconsin. 


\section{State and Federal Updates}

\section{Global Solar Deployment}

\section{U.S. PV Deployment}

\section{PV System Pricing}

\section{Global Manufacturing}

6 Component Pricing
- Currently, the largest solar PV system in the world is a 1.5-GW facility in China; however, 2 GW-projects (or parks) are in development in Egypt, India, and China.

- In 2018, renewables generated more electricity $(41 \%)$ in Germany than coal (38\%) - a first.

- An IEA report projects 4.3 GW-AC of global CSP installations from 2018 to 2023. 


\section{World's Largest PV System}

- In 2006, the largest PV system in the world was an 11-MW facility in Germany.

- Currently, the largest PV system in the world is a 1.5-GW facility in China; however, 2-GW projects (or parks) are in development in Egypt, India, and China.

Erlasee Solar Park

11.4 MW

0.8 miles wide

rano.
(C) 2009 Google Maps

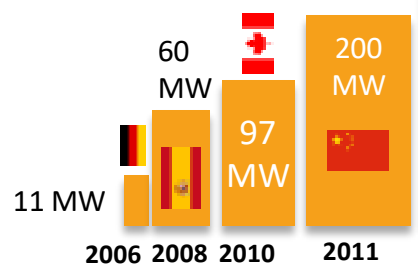

333

MW

垔

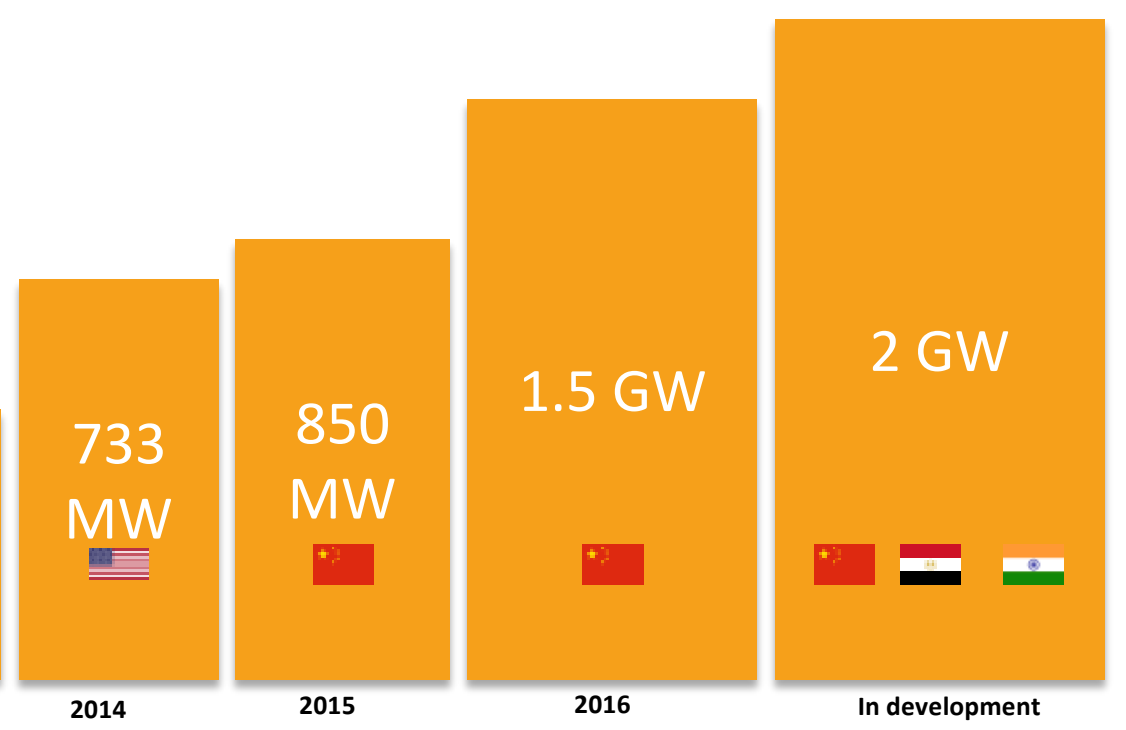




\section{German Electricity Generation by Source}

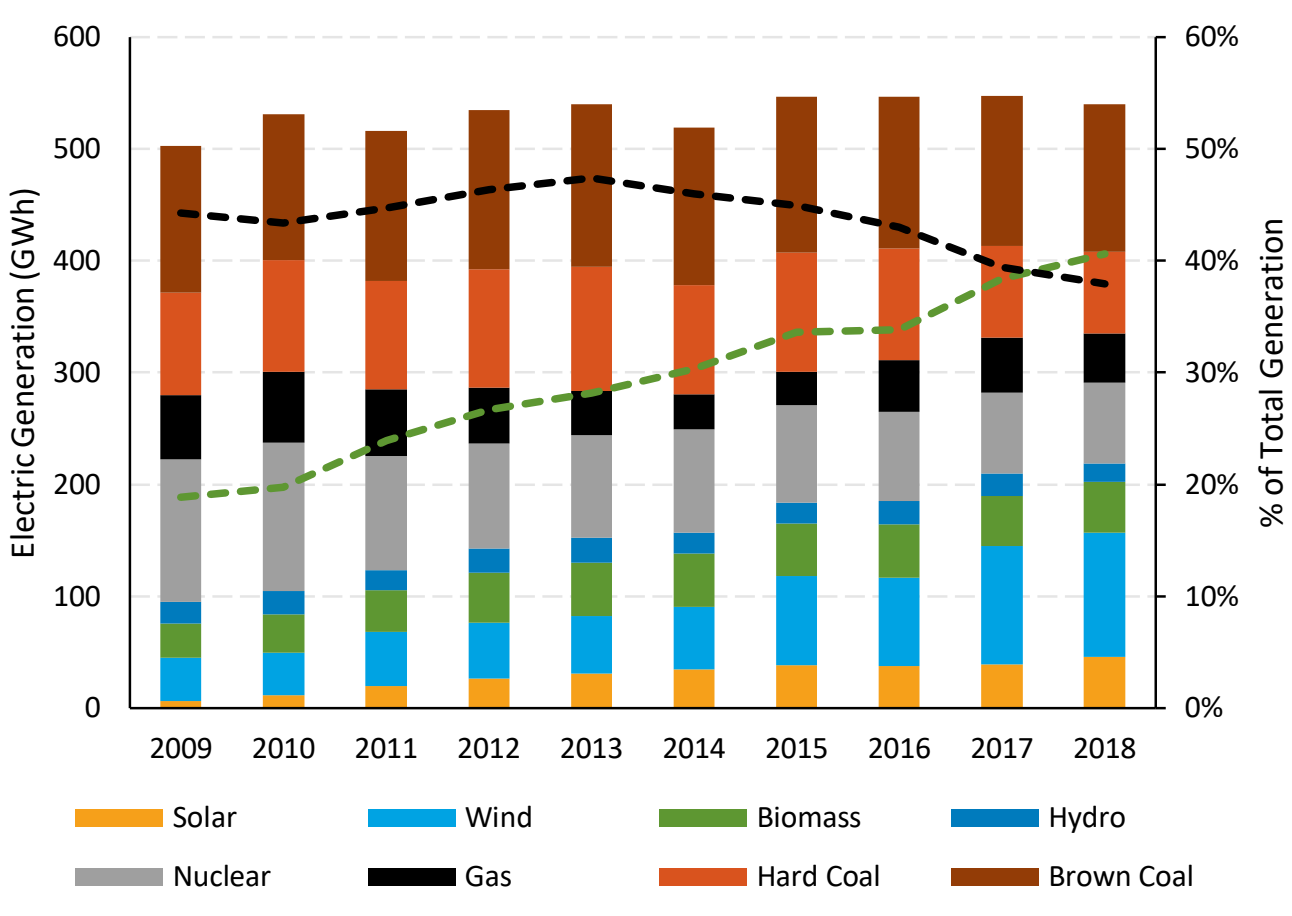

- $\%$ Renewables _ _ $\%$ Coal
- In 2018 , renewables generated more electricity (41\%) in Germany than coal (38\%)-a first.

- From November 2017 to October 2018, the United States generated $18 \%$ from renewables and $27 \%$ from coal.

- An increase in solar generation in Germany coincided more with a decrease in nuclear electricity production than a decrease in coal production.

- From 2009 to 2014, solar generation increased 28 $\mathrm{GWh}$, while nuclear generation decreased $36 \mathrm{GWh}$.

- Electricity from coal actually increased 16 GWh over the same period.

- The drop in electricity from coal coincided more with an increase in wind than an increase in solar.

- From 2014 to 2018, wind and solar generation increased $55 \mathrm{GWh}$ and $11 \mathrm{GWh}$, respectively, while coal and nuclear generation decreased $34 \mathrm{GWh}$ and $20 \mathrm{GWh}$, respectively. 


\section{Recent Developments in CSP Sector PV and CSP}

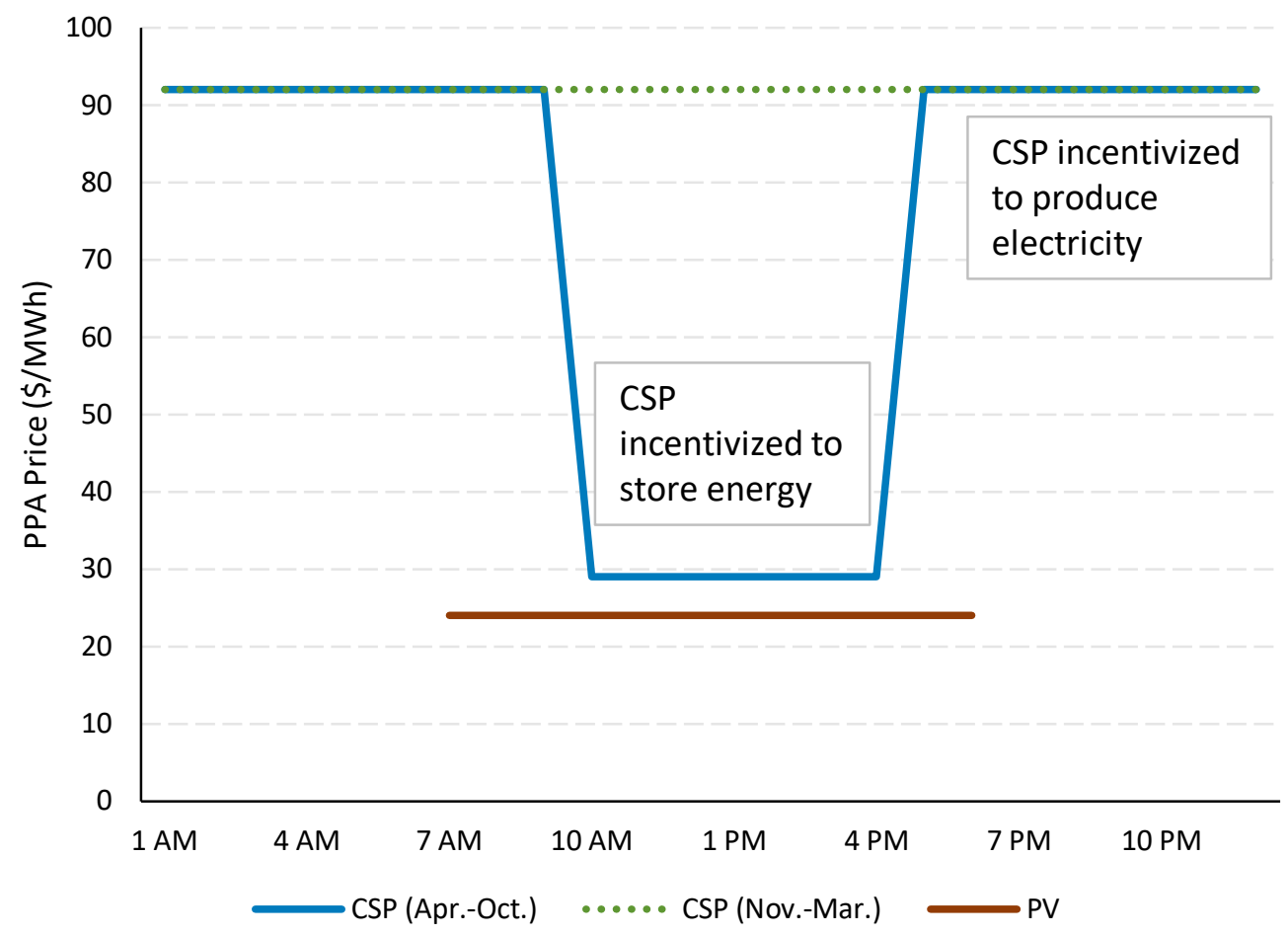

- In December 2018, the Dubai Electricity Water and Authority (DEWA) announced it would add $250 \mathrm{MW}-\mathrm{AC}$ of PV to its 700 MW-AC Mohammed bin Rashid AI Maktoum CSP project.

- The CSP plant, with 15 hours of storage, was awarded at a record low PPA price of $\$ 73 / \mathrm{MWh}$ (\$29/MWh from $10 A M-4 P M$ in the seven-month summer period, $\$ 92 / \mathrm{MWh}$ at other times).

- The PV plant was also awarded a PPA price of $\$ 24 / \mathrm{MWh}$

- The PPA is structured to encourage CSP energy storage during the day, relying more heavily on PV production for the daytime.

- Morocco also believes there are valuable coupling gains with a hybrid CSP-PV project, and it is in the final stages of tendering a PPA, which New Energy Update believes could be at a record low level. 


\section{Recent Developments in CSP Sector IEA Projections, 2018-2023}

- In October 2018, the IEA released its Renewables 2018 report, in which they project $4.3 \mathrm{GW}-\mathrm{AC}$ of CSP will be installed from 2018 to 2023 in its main case, and $6.9 \mathrm{GW}-\mathrm{AC}$ under an accelerated scenario.

\section{CSP Historical Installs and Projections (IEA)}

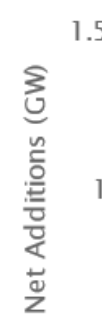

0

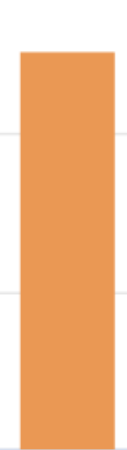

2013

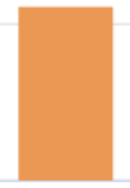

2014

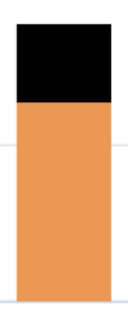

2018

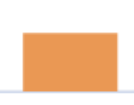

2015

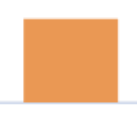

2016
IEA projects most installations will come from China (1.9 GW), Morocco and South Africa (1 GW), and the Middle East ( $1 \mathrm{GW})$.

- This represents $32 \%$ faster growth for CSP than from 2012 to 2017. 


\section{Recent Developments in CSP Sector Enhanced Oil Recovery}

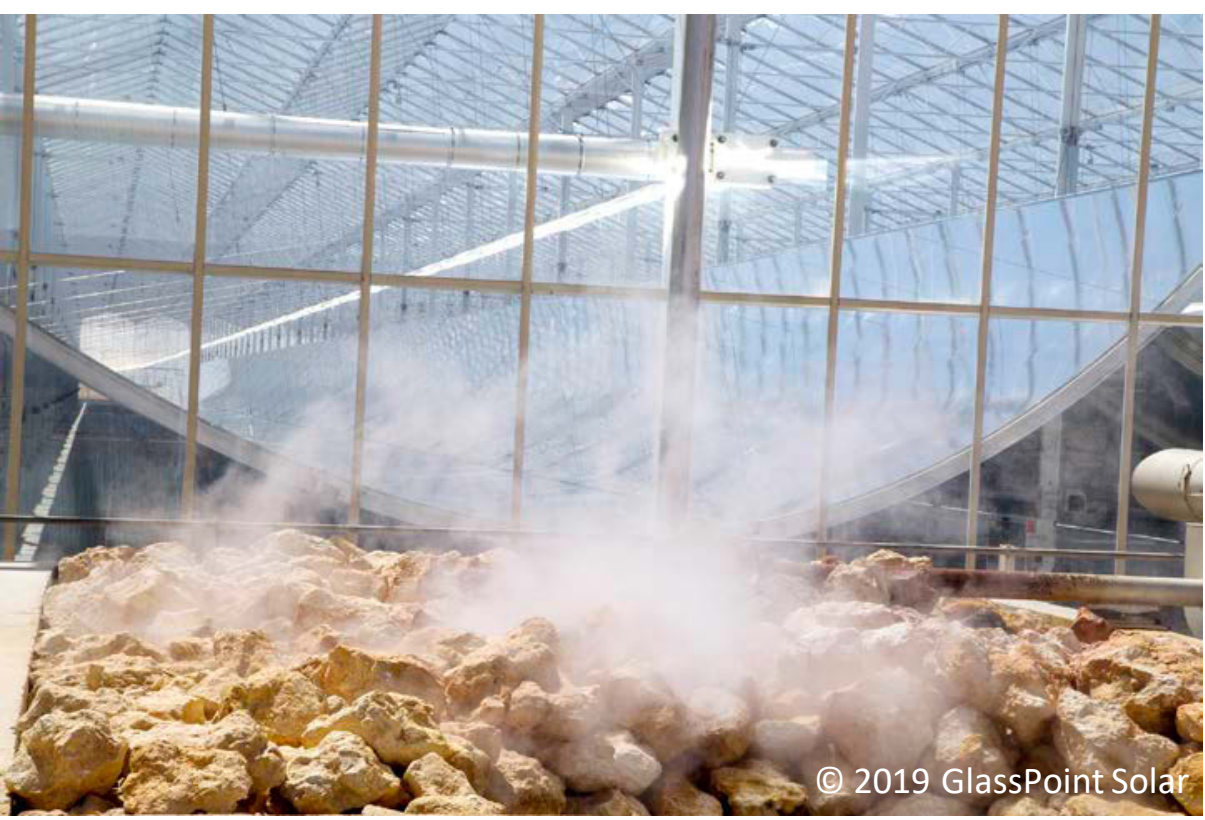

- GlassPoint signed a memorandum of understanding to develop a $2 \mathrm{GW}$-th solar thermal plant for enhanced oil recovery in Oman.

- GlassPoint is already developing a $1 \mathrm{GW}$-th solar thermal plant for enhanced oil recovery in Oman and is already supplying steam from 4 of the 36 planned generation blocks. 
State and Federal Updates

\section{Global Solar Deployment}

\section{U.S. PV Deployment}

\section{PV System Pricing}

\section{Global Manufacturing}

6 Component Pricing

7 Market Activity
- EIA estimates $\mathbf{2 3 \%}$ of all new electricity generating capacity came from solar installations in 2018-second to natural gas.

- Utility-scale contributed 39\% to Q3 2018 installations, its lowest level since Q1 2012. Wood Mackenzie attributes the low level of utility-scale installation to uncertainty of the impacts of the Section 201 tariff in 2017.

- At the end of October, there were 47.0 GW-AC of solar PV systems in the United States, of which 28.0 GW were utility-scale PV and $\mathbf{1 9 . 0}$ GW were distributed PV.

- In January 2019, the California IOU PG\&E declared bankruptcy, putting into doubt higherpriced PPAs from PV systems signed several years ago. 


\section{PG\&E Declares Bankruptcy}

- In January 2019, the California IOU PG\&E declared bankruptcy, due to an estimated \$30B in liability costs related to the company's role in the California wildfires of 2017 and 2018.

- Until this month, PG\&E had been rated investment grade, in part due to the belief that it would seek aid from California. Instead of protection through the legislature, they are seeking protection through the courts.

- In 2001, PG\&E sought Chapter 11 bankruptcy after complications from deregulation.

- SEPA reports that at the end of 2017 PG\&E had the second-most solar of any utility in the country, with just shy of 7 GW-AC, representing $1 / 6$ of all U.S. solar capacity.

- Chapter 11 bankruptcy allows PG\&E to continue operations while restructuring financially, meaning they could seek to cancel or renegotiate contracts. PG\&E signed many PPAs with solar facilities at much higher prices than current market rates.

- Credit Suisse estimates PG\&E could save \$2.2B a year renegotiating renewable power contracts down to current levels.

- The contracts include those from projects that have guarantees from the DOE Loan Program on a portion of \$8.3B in loans.

- Several solar companies that supply PG\&E with power (e.g., Con Edison, yieldcos, and Topaz Solar Farms) have been downgraded by ratings agencies or their stock value has fallen.

- Some experts believe it may be hard for PG\&E to renegotiate power contracts, or it may have to pay damages for breach of contract.

- PG\&E currently has enough money to operate.

- California is aggressively pursuing clean power adoption and canceled contracts might scare potential investors. 


\section{PV Curtailment: Contract Structures}

Existing PPA structures generally address curtailment in one of three ways:

- Take-or-pay: The offtaker agrees to buy all output-delivered and curtailed-at the settled PPA rate.

- Reduced take-or-pay: The PPA contract terms include separate rates for delivered PV output and curtailed PV output, with the curtailed rate being lower than the delivered rate. Alternatively, the offtaker may only compensate for curtailment under certain conditions (e.g., for economic curtailment but not for exceptional dispatches).

- Non-compensable curtailment: The offtaker only pays for delivered energy; the generator bears the full risk of curtailment.

New PPA structures are being explored that would impact the distribution of curtailment risk between the offtaker and the generator, including:

- Capacity plus energy PPA: The offtaker pays the generator a fixed capacity $(\$ / \mathrm{MW})$ rate in addition to the standard volumetric $(\$ / \mathrm{MWh})$ rate.

- Fixed lease: The offtaker pays a fixed monthly lease rate to fully control the generator. 


\section{PV Curtailment: Implementation}

\section{Curtailment has been increasing in the Midwest (for wind) and California and Hawaii (for PV). The implementation of curtailment varies in these three regions.}

\section{Economic}

\section{Midwest}

Curtailment is managed by the Midwest System Operator (MISO). Starting in 2011, MISO requires wind farms to offer energy into the real-time market and participate in security-constrained economic dispatch, which requires them to curtail for economic reasons for all but extreme circumstances.

Source: Greentech Media, 03/23/15.

\section{California}

Curtailment is managed by the California Independent System Operator (CAISO). In the event of a need for curtailment, CAISO first attempts to curtail through low or negative pricing. It may also accept offers from generators to curtail at some level of compensation, known as decremental bids. These economic measures resolve the issue in most cases. In rare events, CAISO manually curtails generators through an "exceptional dispatch." However, most renewable energy procurement in CAISO is managed by its three IOUs, which have an incentive to optimize their own portfolios.

\section{Manual}

\section{Hawaii}

Curtailment is managed by the Hawaiian Electric Company (HECO) based on system needs. HECO curtails generators in reverse chronological order (i.e., newer generators are curtailed before older generators). 


\section{PV Curtailment: Trends to Date}

\section{California}

- CAISO curtailed about 420,000 MWh of PV output in 2018about $1.6 \%$ of systemwide PV output.

- PV curtailment was highest in the spring when hydropower capacity peaked and electricity demand was relatively low.

\section{Hawaii}

- By one estimate, expected curtailment levels for new PPAs are about $10 \%$ on O'ahu, and $20 \%-50 \%$ on Maui and Hawaii (Sterling et al. 2017).

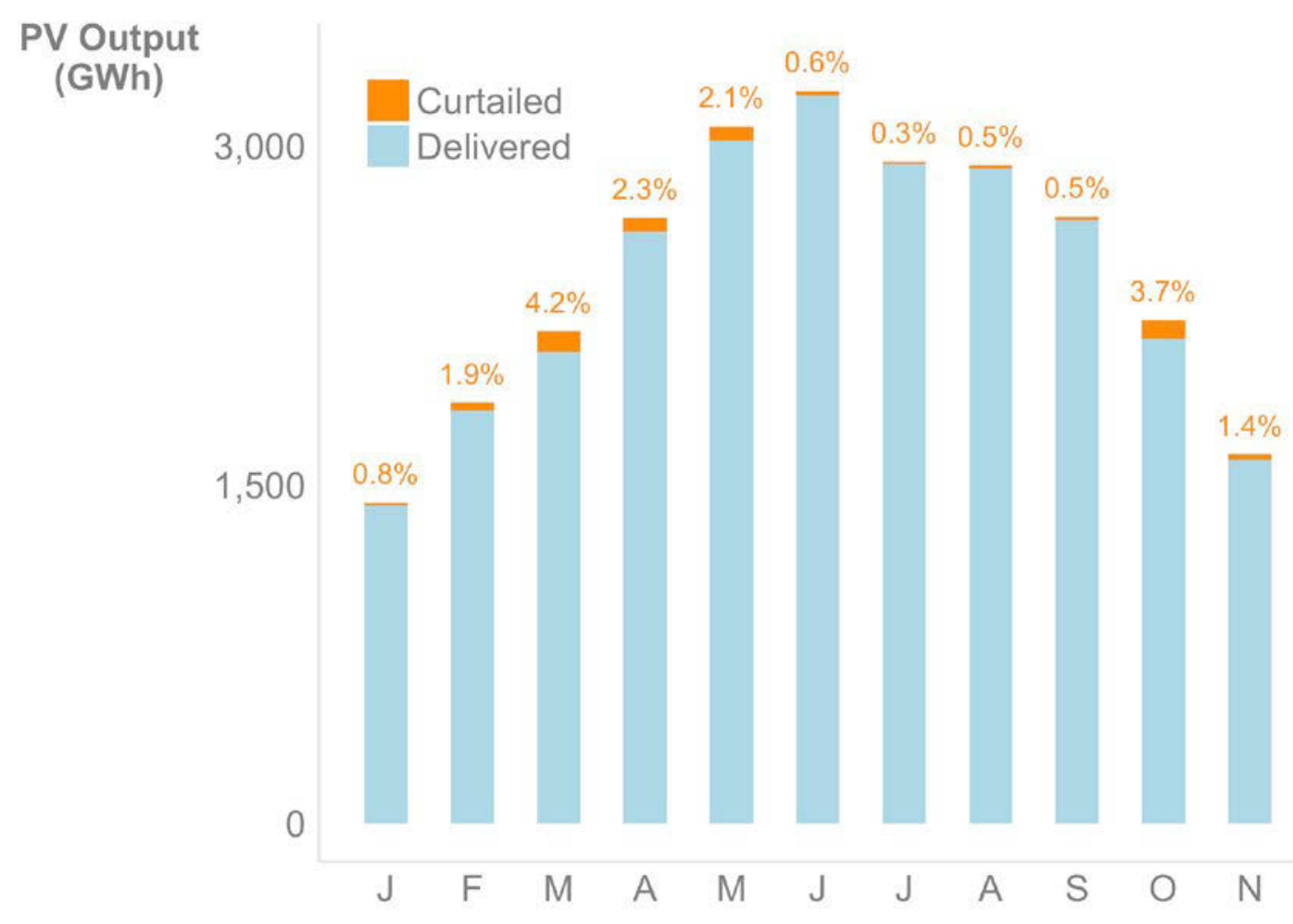

Monthly Delivered and Curtailed PV Output in the CAISO System Based on data obtained from CAISO 


\section{High-Resolution Imagery Used to Map U.S. PV}

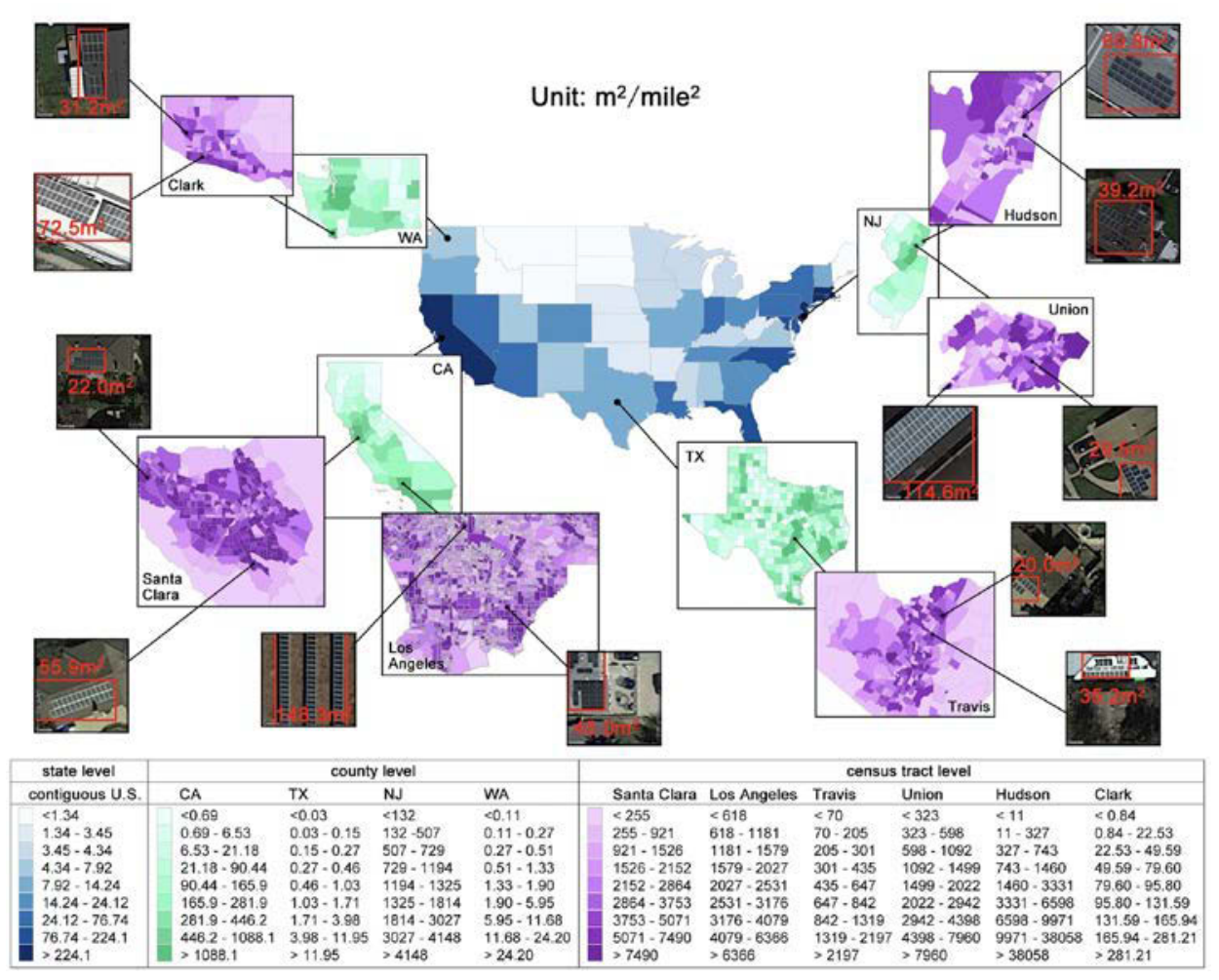

- Stanford researchers analyzed billions of high-resolution satellite images to identify the locations and sizes of solar PV panels in the contiguous United States, finding 1.47 million individual solar installations, including small rooftop, commercial, and utilityscale systems.

- SEIA reported 1.82 million PV systems in the contiguous United States as of Q3 2018.

- Using these data, researchers looked at deployment information together with other variables and found that higher levels of deployment have occurred where:

- Population density is 1,000 people per square mile, or greater

- Solar radiation averages at least $4.5 \mathrm{kWh} / \mathrm{m}^{2} /$ day

- Average annual household income is at or above $\$ 150,000$.

- The researchers also found that PV deployment decreases in areas with greater income inequality.

- The researchers argue this type of data could also be used to plan infrastructure upgrades, identify areas in need of solar deployment, or as a predictor model for adoption.

- The DeepSolar database was made publicly available to researchers, utilities, solar developers and policymakers. 


\section{Green Banks}

- A green bank is a public, not-for-profit financial institution that leverages limited public dollars to drive private capital investment in clean power goods and services.

- Green banks are designed to jump-start new markets, such as LMI solar, providing road maps and data to de-risk asset classes and allow other investors to enter.

- Green banks can be established at the state (CA), county (Montgomery Country, MD), or city (New York City) level.

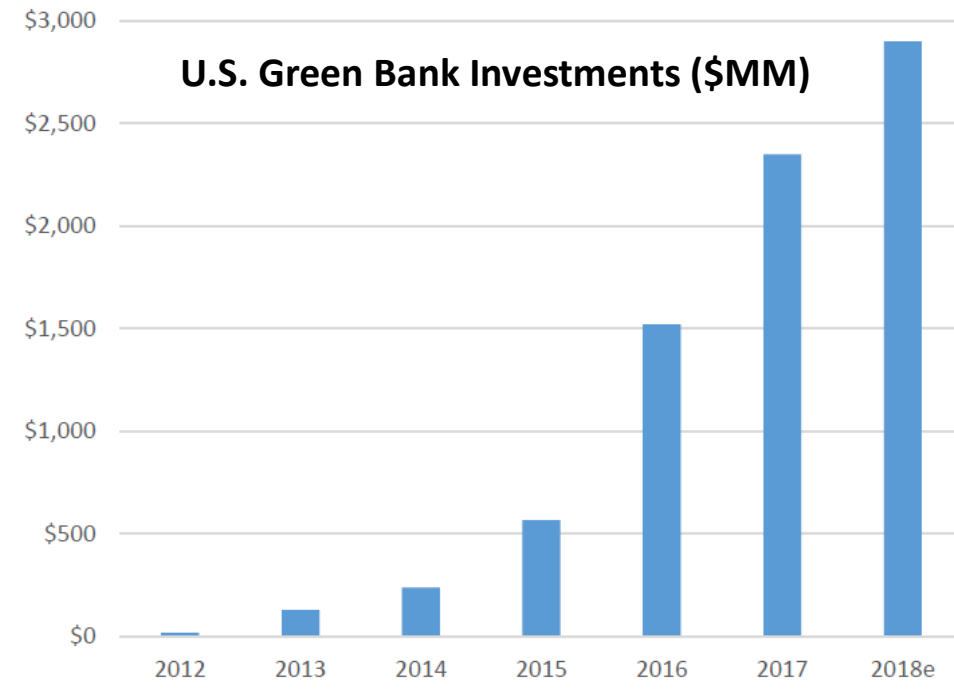

- The Green Bank Network, an international network of green banks, estimates green banks have made $\$ 41 \mathrm{~B}$ in transactions globally.

- Green banks in Connecticut, New York, and Rhode Island are part of the international network.

- Over 15 green banks are currently operating in a dozen states in the United States.

- The Coalition for Green Capital estimates these institutions mobilized \$3B in public and private capital for clean energy projects in 2018.

- Some of these green banks have moved beyond state boundaries and are active in other states.

- In addition to green banks, traditional banks have started new efforts in sustainable finance.

- In December 2018, Bloomberg announced the launch of the U.S. Alliance for Sustainable Finance-whose 15 founding members represent some of the largest banks in the world-with the mission of driving sustainable finance innovation.

- These banks have over $\$ 18.525 \mathrm{~B}$ in assets on their balance sheet. 


\section{The Potential to Increase Solar Adoption for LMI Customers}

- $\quad$ NREL estimates LMI rooftop solar technical potential is over $300 \mathrm{GW}$ in the U.S. Sixty percent of the potential is on multifamily and renter-occupied buildings.

- NREL surveyed LMI customers and found the two primary reasons for solar adoption to be being able to save on electricity bills and being influenced by their peers' actions.

- $\quad$ Randomized controlled trials in Connecticut, carried out by researchers at Yale, show that the decision to go solar by LMI adopters is influenced by social factors such as local events, effective solar ambassadors and town representatives, and connection to solar peers.

- Visual exposure to solar (especially seeing a solar rooftop project from the street) increased the average number of installations within a half-mile radius by nearly $50 \%$.

- In communications campaigns, individual-oriented messages focusing on personal financial benefits, including the stabilization of energy bills, yielded higher solar installation rates.

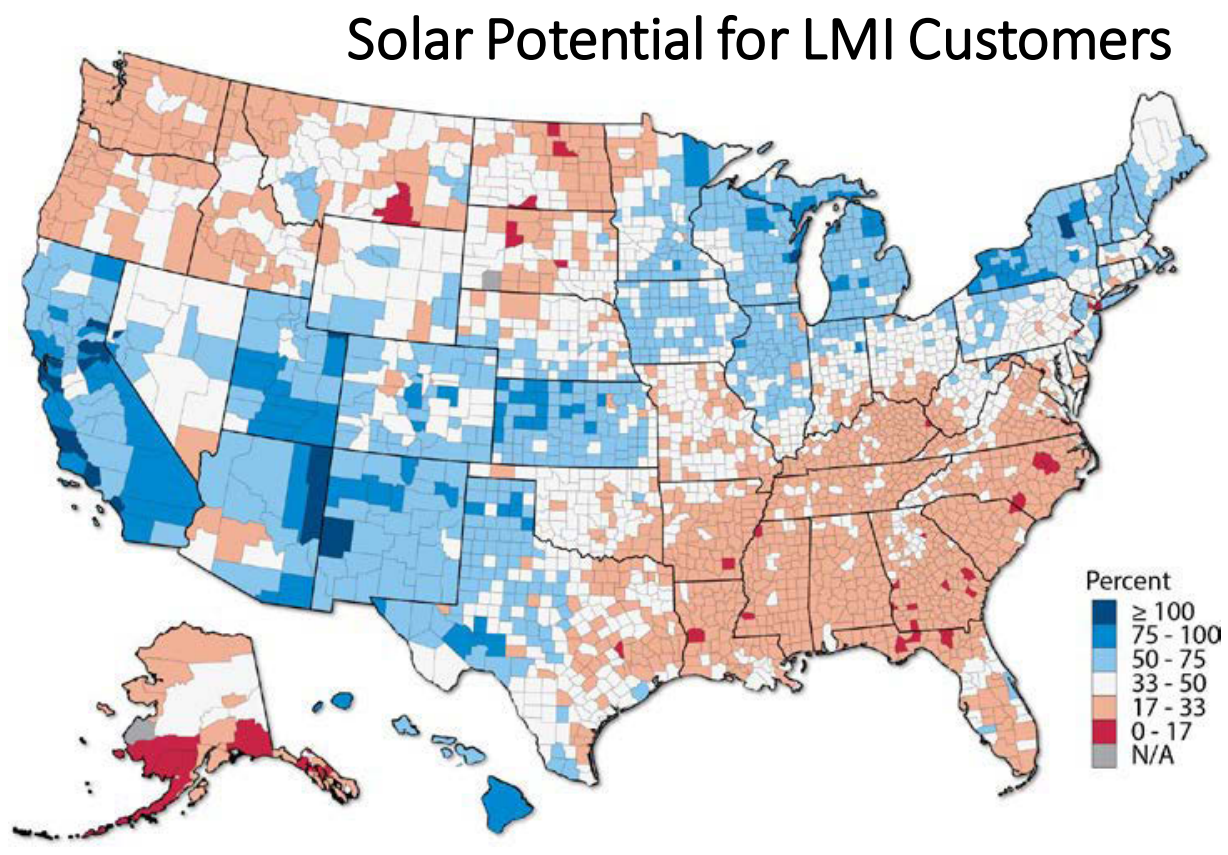

Percentage of LMI electricity consumption offsettable by rooftop solar using only single family owner-occupied buildings' roofs
Source: https://www.nrel.gov/solar/seeds/2017-2019-study.html. Data: https://data.nrel.gov/submissions/81.
Kenneth Gillingham Ben Sigrin 


\section{U.S. Generation Capacity Additions by Source: 2017 and Estimated 2018}

- EIA estimates $23 \%$ of all new electricity generating capacity came from solar installations in 2018-second to natural gas.

- Based on data through October 2018, solar capacity additions are expected to increase $y / y$.

- 2018 will likely be the first year since 2013 that solar and wind represented less than $50 \%$ of annual generation capacity additions.

Estimated 2018 U.S. Generation Capacity Additions (Total $39.3 \mathrm{GW}$ )

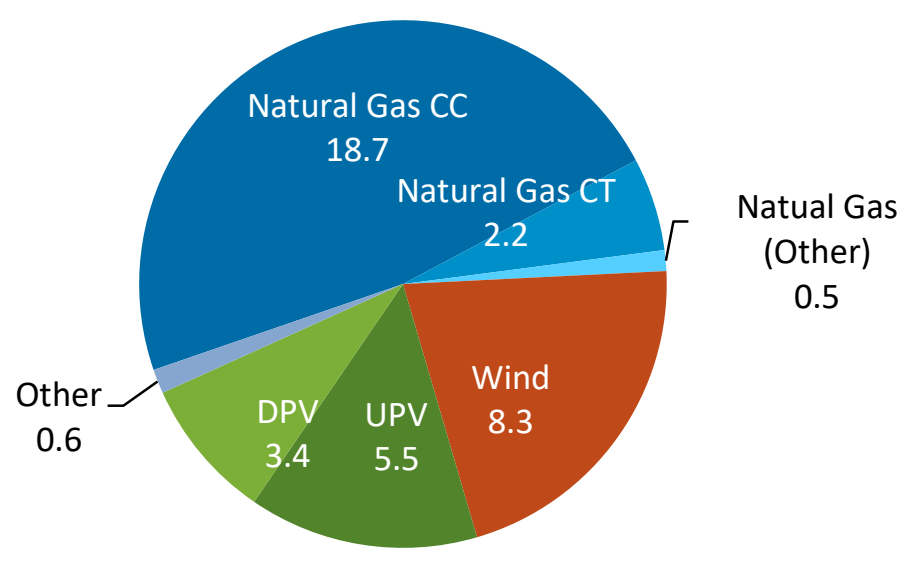

- Based on EIA data through October 2018, it is estimated that $39 \mathrm{GW}$ of new electric generating capacity came online in 2018-up from $25.9 \mathrm{GW}$ in 2017.

- $24.7 \mathrm{GW}$ came online from January through October 2018, and another $14.6 \mathrm{GW}(37 \%)$ is estimated to have come online in November and December.

- A large part of this increase is due to the expected addition of $21 \mathrm{GW}$ of natural gas plants-up from 10.5 GW in 2017.

- Wind additions are expected to also have increased by one-third as well.

\section{U.S. Generation Capacity Additions (Total $25.9 \mathrm{GW}$ )}

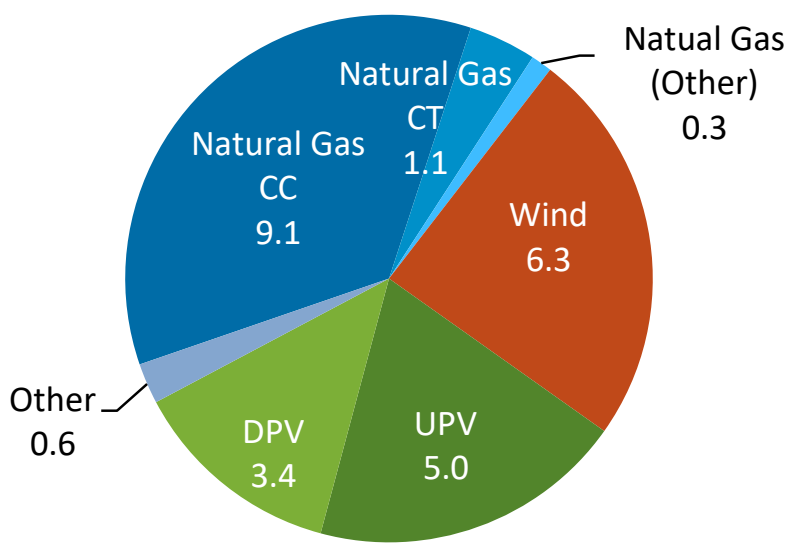




\section{U.S. Installation Breakdown by State}

At the end of October, there were $47.0 \mathrm{GW}-\mathrm{AC}$ of solar systems in the United States, of which $28.0 \mathrm{GW}$ were utility-scale PV and $19.0 \mathrm{GW}$ were distributed PV.

Cumulative Installed Capacity, Top 10 States as of Oct. 2018 Megawatts (MW-AC)

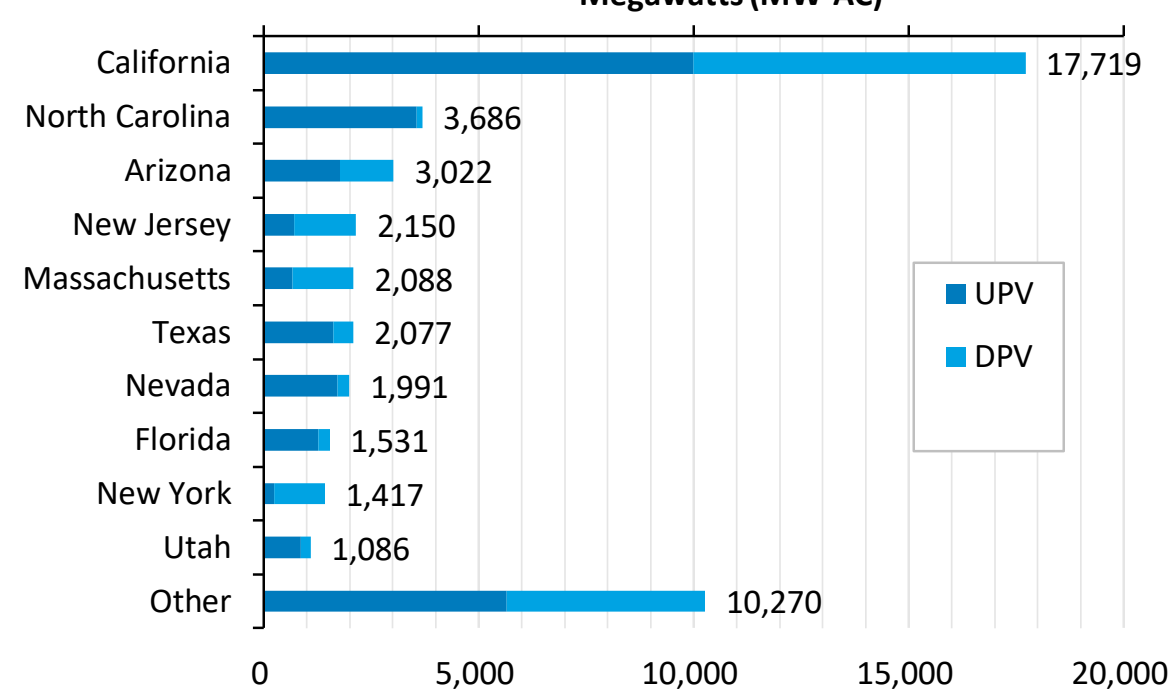

From October 2017 to October 2018 approximately 8.5 GW-AC of PV capacity was installed, of which 5.0 GW-AC were utility-scale PV and 3.5 GW-AC were distributed PV.

Installed Capacity, Top 10 States, from Oct. 2017 to Oct. 2018 Megawatts (MW-AC)

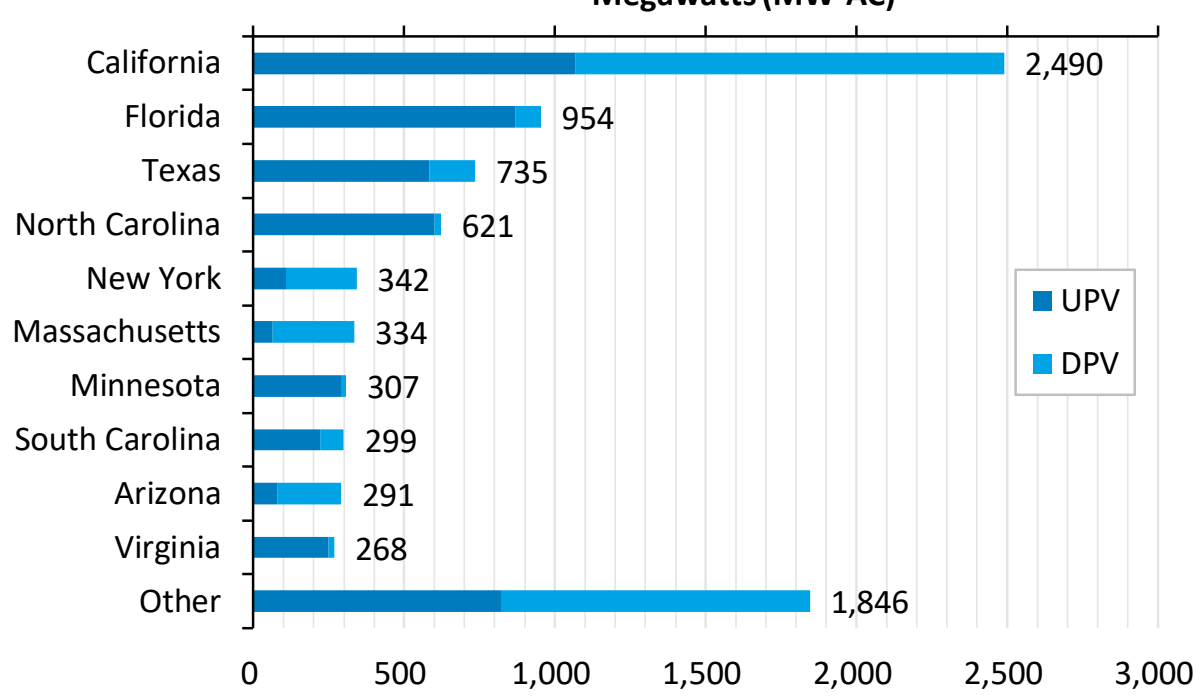

Note: EIA monthly data for 2018 are not final. Additionally, smaller utilities report information to EIA on a yearly basis, and therefore, a certain amount of solar data has not yet been reported. "Net Generation" includes DPV generation. Sources: EIA, “Electric Power Monthly,” forms EIA-023, EIA-826, and EIA-861 (December 2018). 


\section{Historical U.S. Interest Rates}

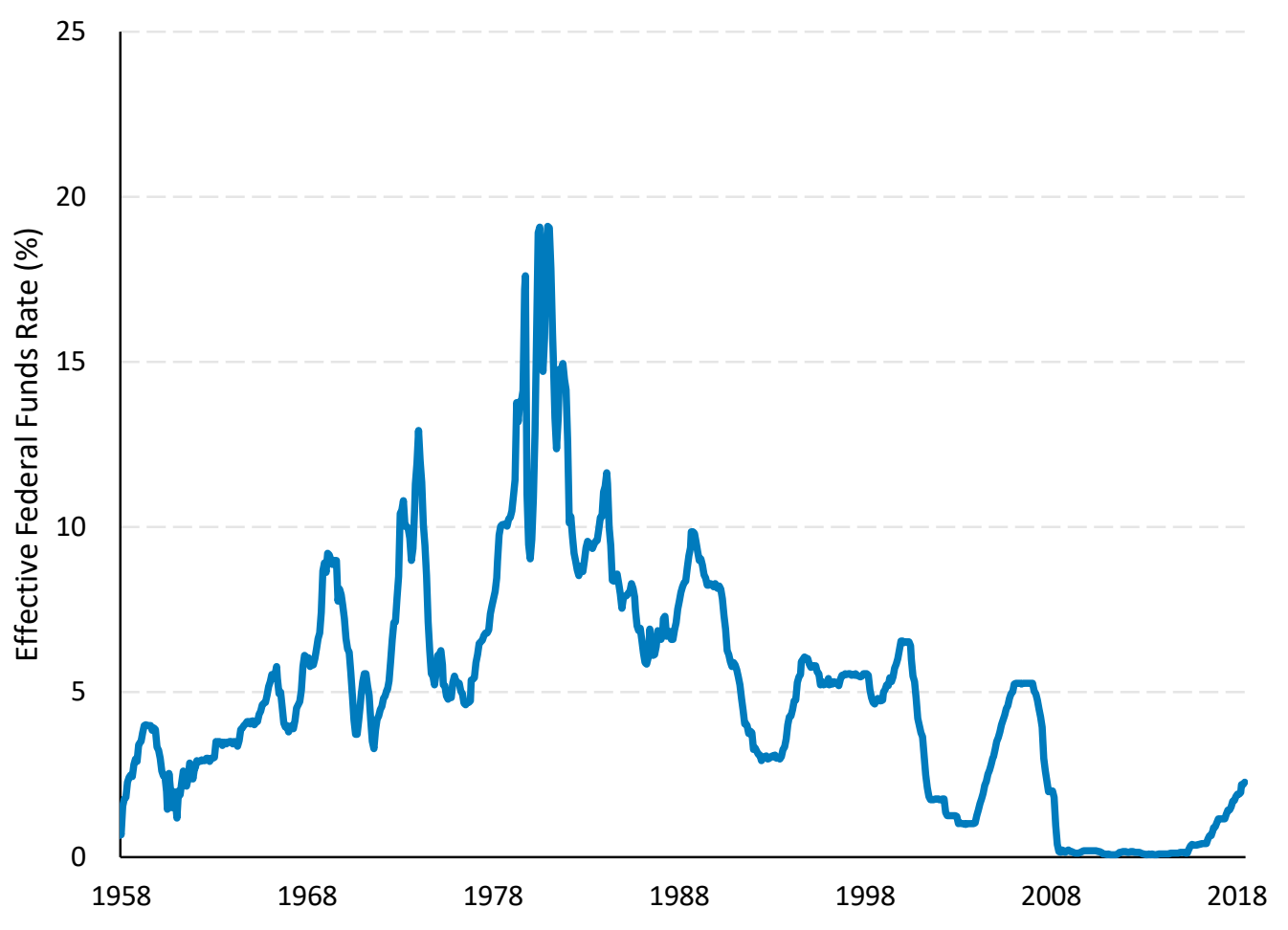

- The vast majority of U.S. PV installations have occurred in a historically low-interest rate environment.

- The Federal Funds Rate, which influences virtually all borrowing rates in the United States, has increased by $1.9 \%$ in the past 18 months; however, it is still at a relatively low historical level.

- Some within the solar industry worry further increases in interest rates could dampen solar deployment or could require further reductions in system costs to achieve the same levels. 


\section{Impact of Interest Rate Changes by Energy Technology}

LCOE Impact of a 3\% Increase in Interest Rates

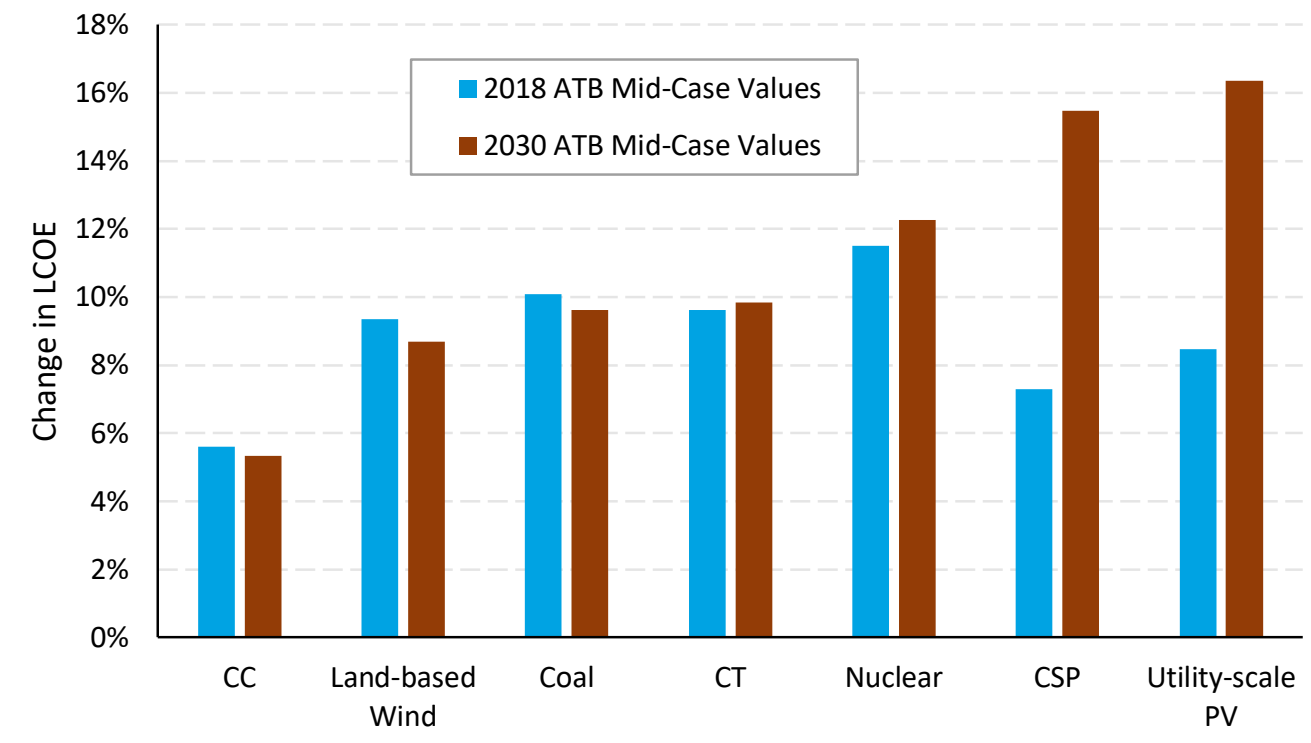

Note: The analysis uses the "mid-case" and "market factor financials" for each technology. Source: NREL 2018 Annual Technology Baseline (ATB): https://atb.nrel.gov/.
- An analysis was performed using NREL's 2018 Annual Technology Baseline (ATB), in which interest rates were increased $3 \%$ for each technology.

- In 2018, solar tended to be less impacted by an increase in interest rates than other technologies.

- The tax credit reduced the impact that upfront capital costs had on LCOE.

- The need for tax equity investors resulted in a lower level of debt, dampening the impact of an increase in interest rates.

- However, by 2030 , assuming no incentives and a higher level of debt, solar technologies were projected to be impacted the most by an increase in interest rates.

- The impact of an increase in interest rate depends on the proportion that upfront capital costs, O\&M, incentives, and fuel have on LCOE, as well as the percent of debt a technology can raise for a project.

- Note that fuel costs and O\&M are also likely to increase with a long-term interest rate environment, which is not captured in the analysis. 


\section{U.S. Installation Breakdown}

- In Q3 2018, the United States installed 1.8 GW-DC of PV, down 15\% y/y.

- Thirty-nine percent of capacity came from utility PV—the lowest level since Q1 2012.

- Wood Mackenzie attributes the low level of utility-scale installation to uncertainty of the impacts of the Section 201 tariff in 2017.

- Since late 2015, the United States has installed approximately 1 GW-DC of distributed PV each quarter.

- More than 400 MW-DC of community solar was installed during the first nine months of 2018.

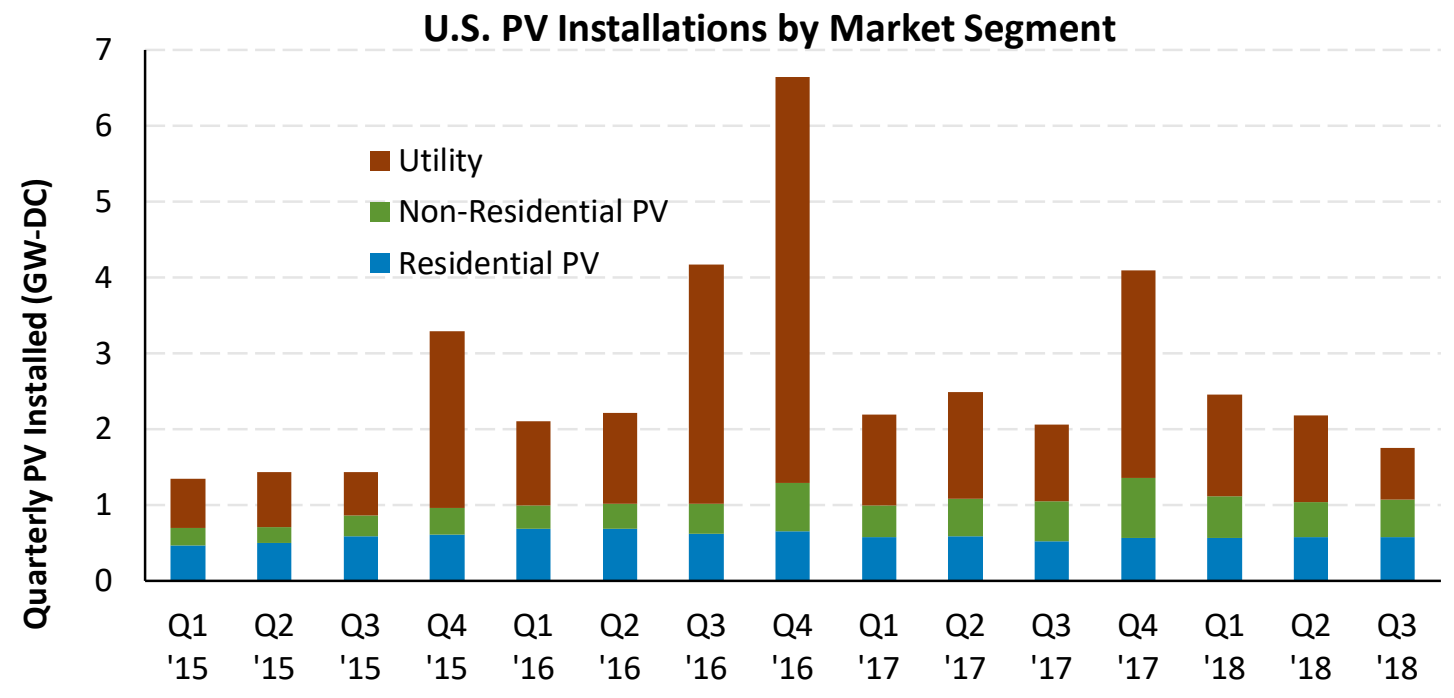

U.S. PV Installations by Region (MW-DC)

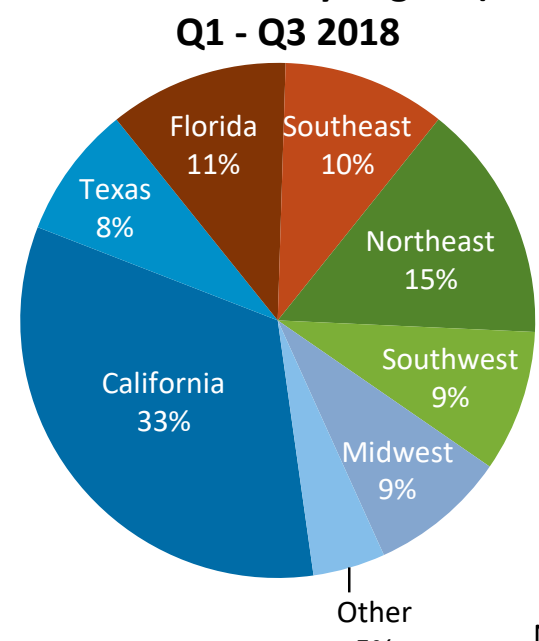


Tesla, Vivint Solar, and Sunrun Residential Market Share

- A modest increase in U.S. residential installations in Q3 2018 was led in large part by increases in large national installers.

- Tesla's direct sales continue to grow as a percentage of total sales, while Sunrun and Vivint still install mostly leased or PPA systems.

- Vivint recently switched its commission incentive structure to favor TPO over customer-owned sales.

- Wood Mackenzie also reports that business for the largest residential PV loan providers has slowed due to tightening credit requirements, rising interest rates, and a desire to achieve profitability.

\section{Residential Installs}

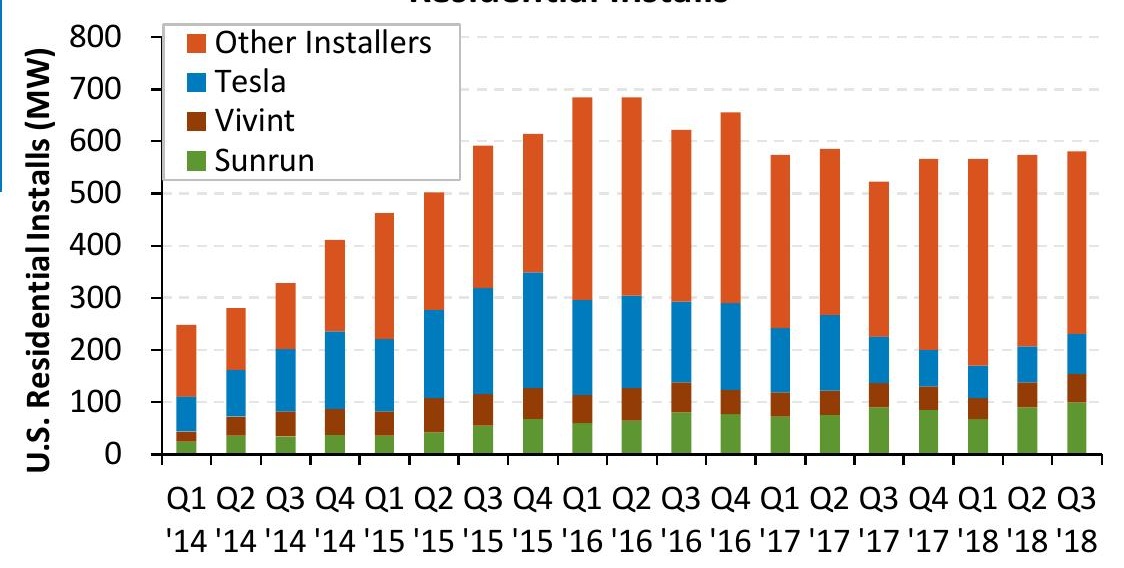

Percentage of Direct Sales/Loans

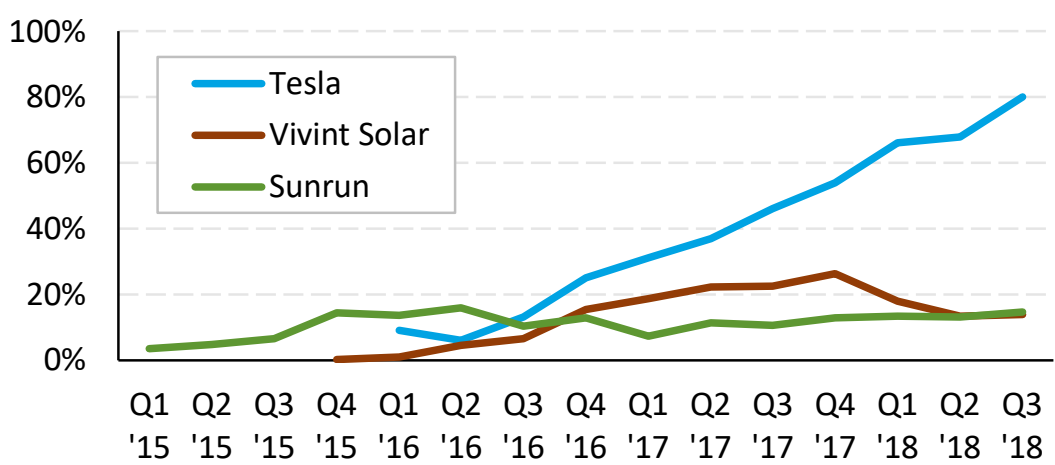




\section{U.S. Utility-scale Solar Set to Take Off}

\section{Solar projects by Independent System Operator (ISO) queue}

- Solar projects in queue (MWac)

- Solar projects $w /$ interconnection agreements*

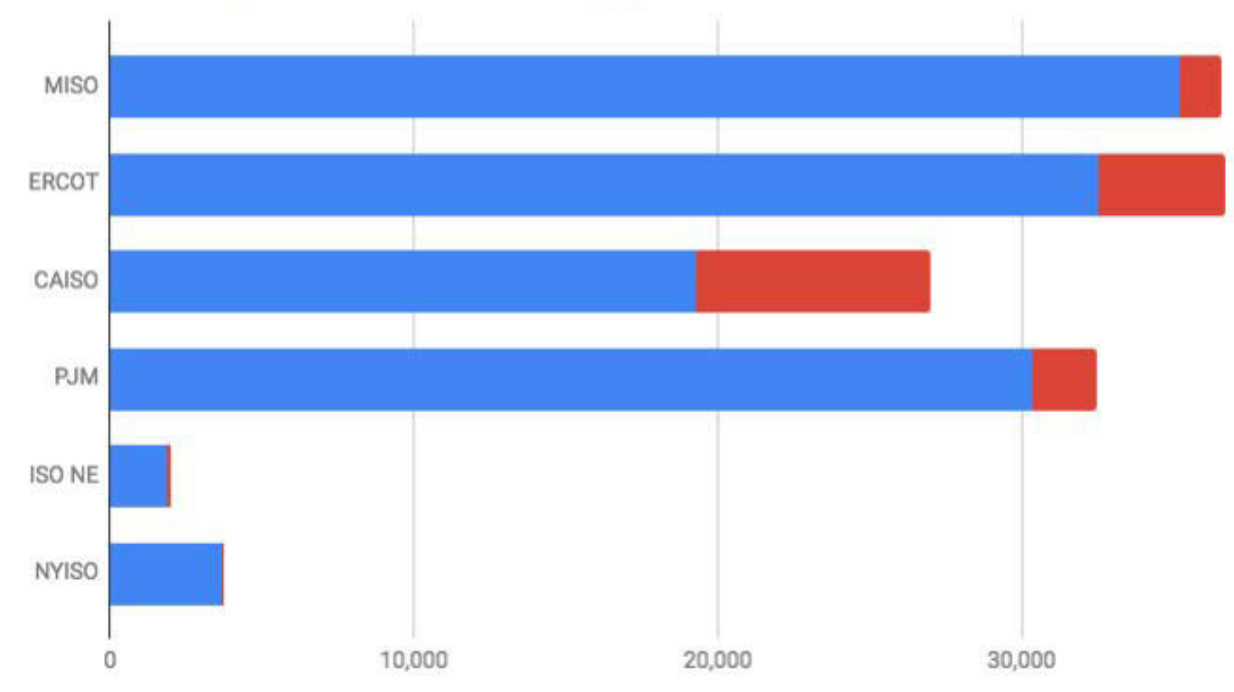

Map of ISO territories

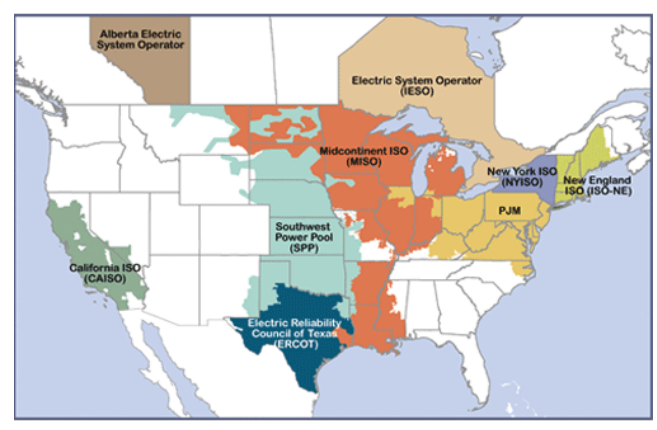

- PV Magazine reports that developers have applied to build $139 \mathrm{GW}$-AC of utility-scale PV systems in six grid-operating territories.

- This figure does not include projects in most of the South, Mountain West, Pacific Northwest, and Plains States.

- However, ISO New England estimates $70 \%$ of the projects in its queue are never completed. Several factors can contribute to projects dropping out of the queue. For example:

- Interconnection upgrades may be cost prohibitive.

- Projects may be unable to finalize power sales contracts or financing. 


\section{California Residential MLPE}

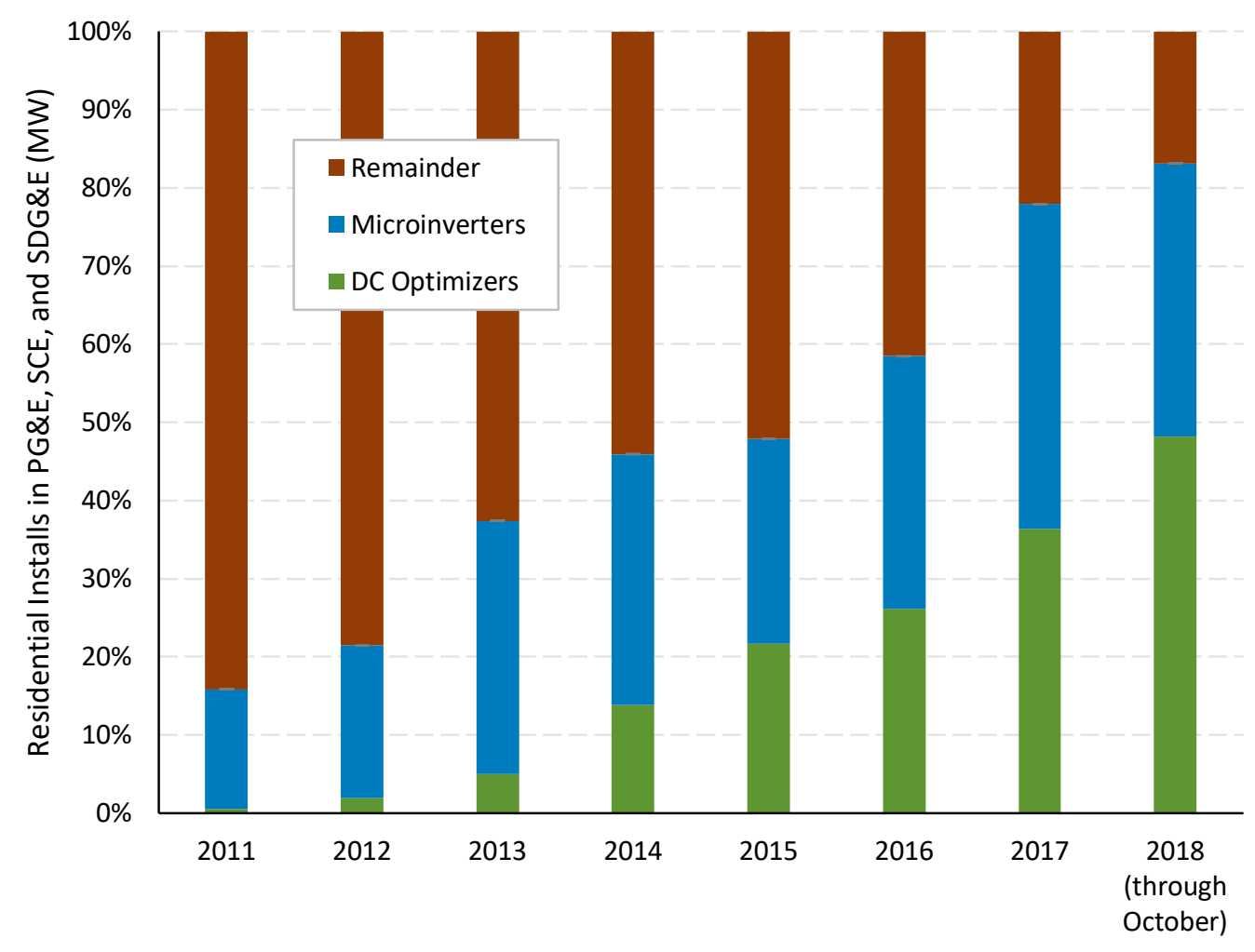

- MLPE continue to gain market-share in the U.S. residential PV market, with $83 \%$ of residential systems in California using a micro-inverter or DC optimizer in 2018.

- An important factor in the shift to MLPE in the California residential PV sector was a change in building codes requiring "rapid shutdown" of PV output. Other states have adopted similar measures.

- The vast majority of systems either use SolarEdge (DC optimizers) or Enphase (micro-inverters).

- SunPower had gained significant market share in the microinverter space but has since sold its inverter business to Enphase. 


\section{California Non-Residential MLPE}

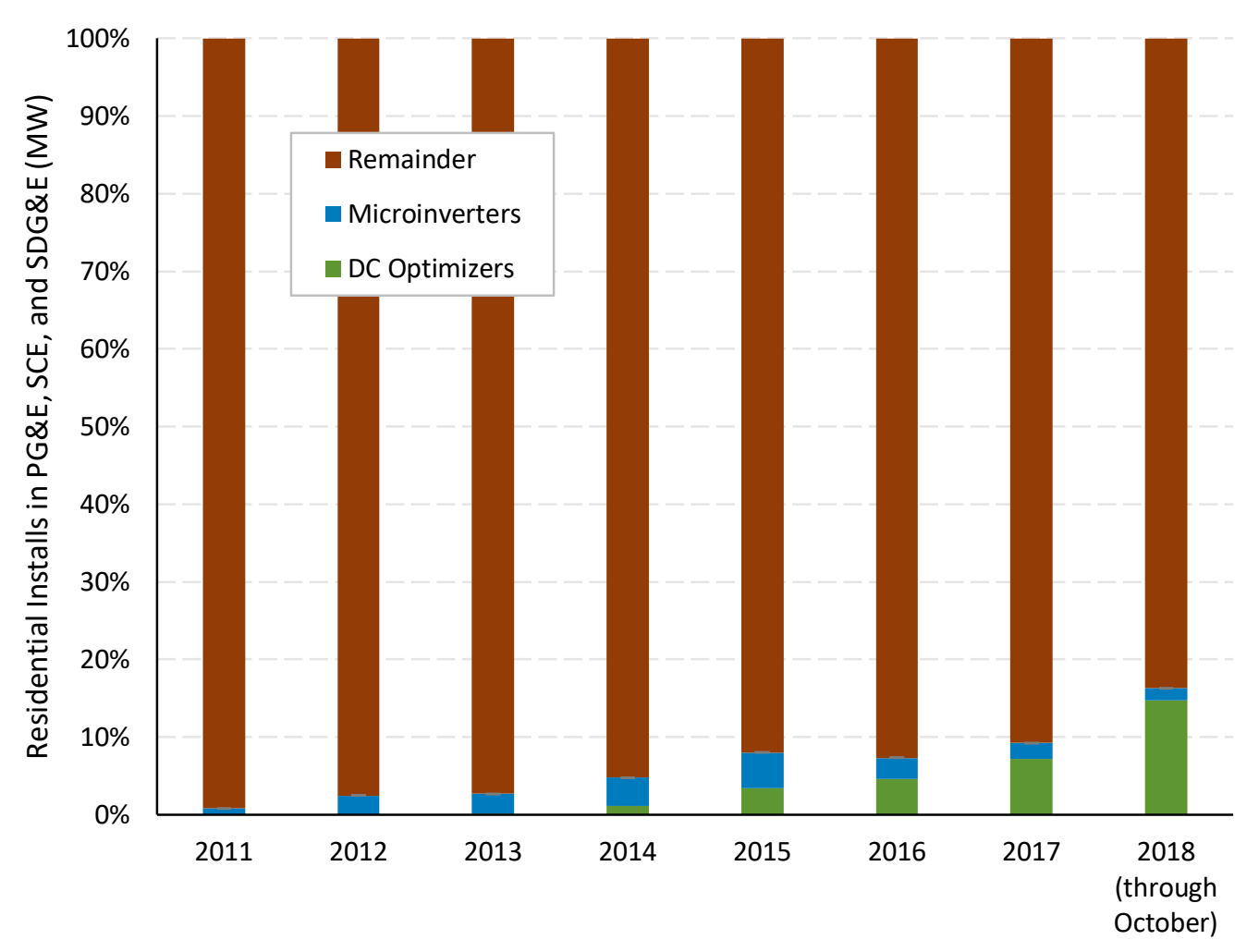

- MLPEs are less common in the non-residential PV market; however, they are becoming more common in non-residential systems, too.

- The share of MLPEs in the California non-residential PV market reached approximately $17 \%$ in 2018. 


\section{U.S. Energy Storage Installations by Market Segment}

- The United States installed approximately $425 \mathrm{MWh}$ (169 MW) of energy storage onto the electric grid in the first nine months of 2018up 28\% y/y, despite the Q1 2017 front-of-the-meter spike.

- The drop in behind-the-meter storage installations, $Q / Q$, was attributed to battery supply constraints. Still, it was the secondlargest quarter on record.

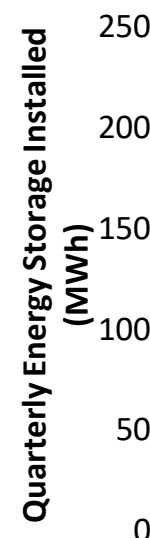

0

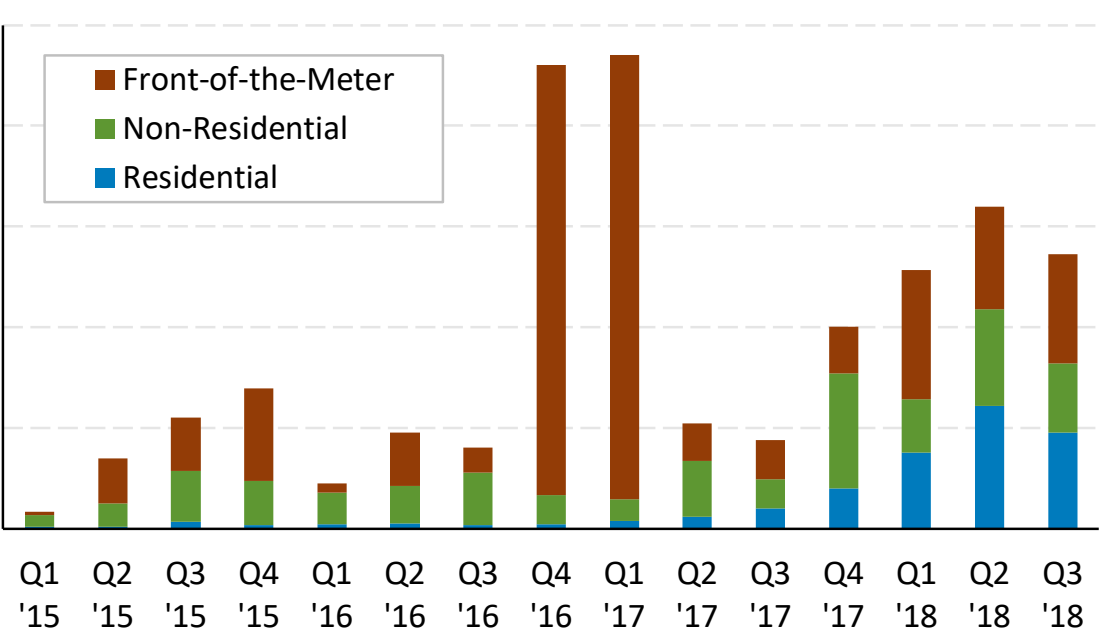

- Of the behind-the-meter storage capacity deployed in Q3 2018, 70\% and 10\% occurred in California and Hawaii respectively.

- Massachusetts is expected to have a large storage market in 2019 due to the rollout of is SREC successor program, SMART. The program provides $\$ 0.03 / \mathrm{kWh}-$ $\$ 0.08 / \mathrm{kWh}$ for storage systems paired with PV that have a discharge duration of at least two hours, have a roundtrip efficiency of at least $65 \%$, and which discharge at least 52 cycles annually.

- In July 2018, California revised its fire code to set more stringent standards on stationary storage using lithiumion batteries. The changes are expected to add costs to certain systems and make others infeasible.

- Outside the major markets, only a few places have policies in place to provide revenue streams that make solar-plus-storage viable. 


\section{U.S. PV Deployment: States with Energy Storage Mandates}

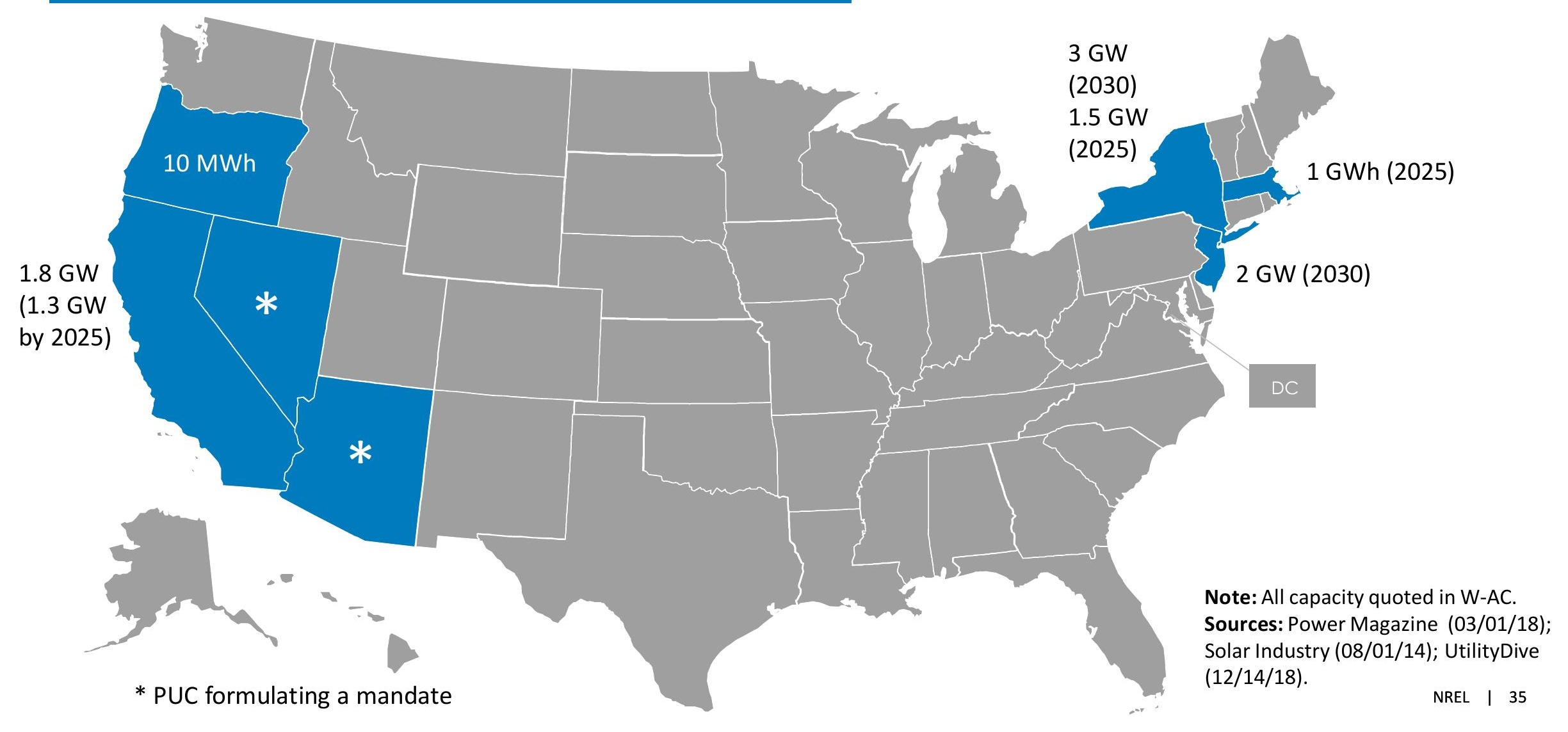


State and Federal Updates

\section{Global Solar Deployment}

\section{U.S. PV Deployment}

4 PV System Pricing

\section{Global Manufacturing}

6 Component Pricing
Based on preliminary reported data, from 2017 to 2018, the median reported PV system price in California, Massachusetts, and New York was relatively flat, though significant price variation remains. 


\section{System Pricing from Select States}

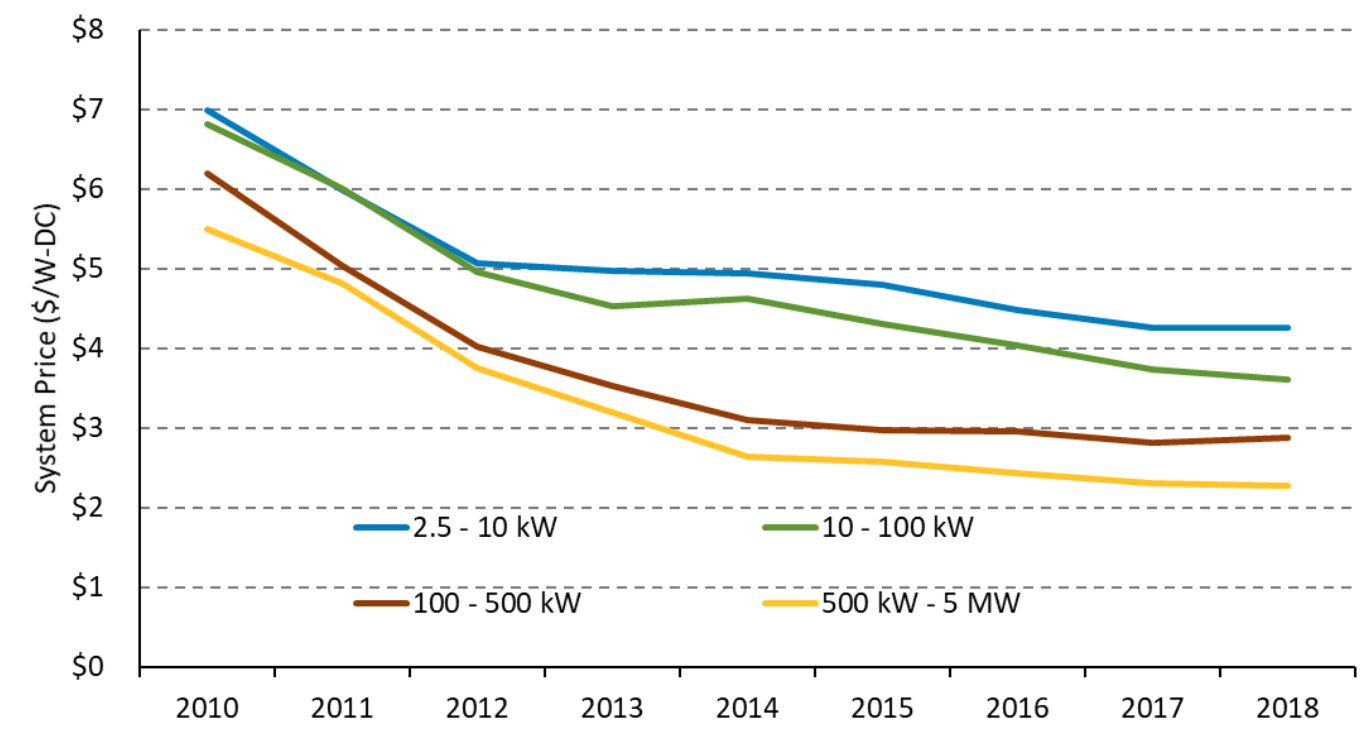

Based on preliminary data, from 2017 to 2018 , the median reported PV system price in California, Massachusetts, and New York:

- Remained flat at $\$ 4.25 / \mathrm{W}$ for systems from 2.5 $\mathrm{kW}$ to $10 \mathrm{~kW}$

- Fell $3 \%$ to $\$ 3.61 / \mathrm{W}$ for systems from $10 \mathrm{~kW}$ to $100 \mathrm{~kW}$

- Increased $2 \%$ to $\$ 2.88 / \mathrm{W}$ for systems from 100 $\mathrm{kW}$ to $500 \mathrm{~kW}$

- Fell $1 \%$ to $\$ 2.27 / \mathrm{W}$ for systems from $500 \mathrm{~kW}$ to $5 \mathrm{MW}$. 


\section{System Pricing from Select States, 2018 (Preliminary)}

- In addition to price differences based on system size, there is also variation between states and within individual markets.

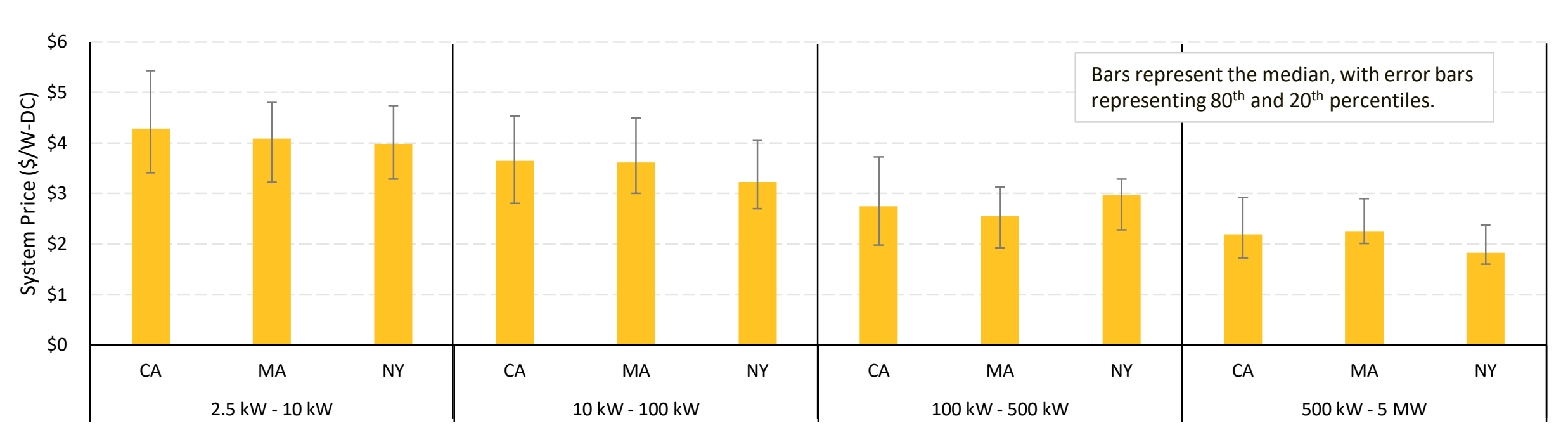

- Based on preliminary data in 2018 , the median price of a small system in New York was about $8 \%$ less than the median price in California.

- In 2018 , the $20^{\text {th }}$ and $80^{\text {th }}$ percentile preliminary prices in California for a small system were $\$ 3.46 / \mathrm{W}$ and $\$ 5.43 / \mathrm{W}$ respectively.

Preliminary 2018 MW: CA (657), MA (218), NY (256)

Note: System prices above $\$ 10 / \mathrm{W}$ and below $\$ 1 / \mathrm{W}$ were removed from the data set.

Sources: CA NEM database (10/31/18); MA SREC program (12/12/18); NYSERDA(11/30/18). 


\section{State and Federal Updates}

\section{Global PV Deployment}

\section{U.S. PV Deployment}

4 PV System Pricing

5 Global Manufacturing

6 Component Pricing
- Performance of solar companies was mixed in Q3 2018, improving on average due to successfully transitioning to low-cost environment.

- Three gigawatts of announced new or refurbished U.S. PV manufacturing capacity is expected to come online in 2019. Peak capacity may also be lower than originally reported, or manufacturers may take time to ramp up to full production. 


\section{U.S. PV \\ Manufacturing Expansion}

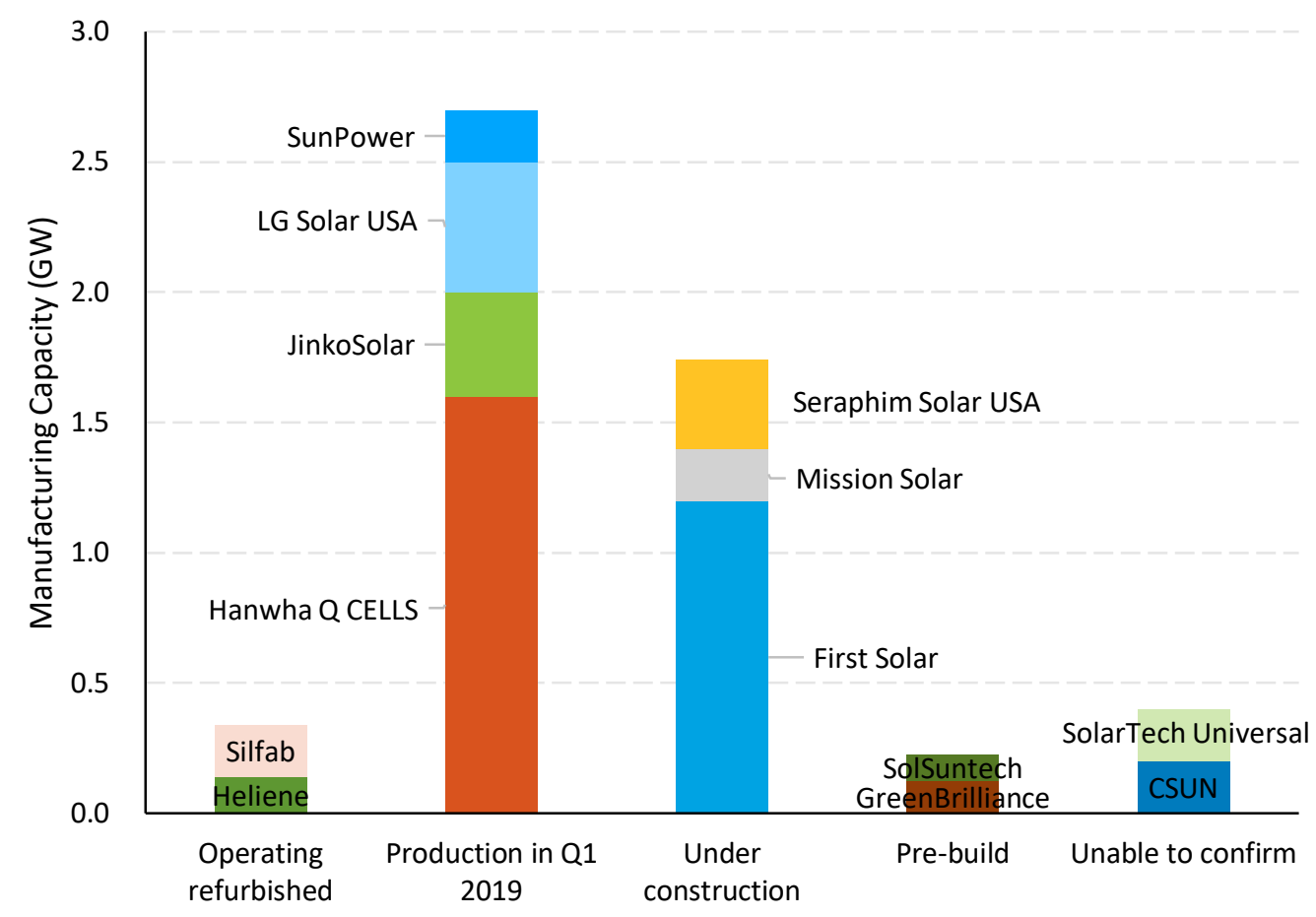

- Solar Power World reports that approximately $340 \mathrm{MW}$ of U.S. manufacturing capacity was refurbished in 2018 and is now currently operating.

- Roughly $2.7 \mathrm{GW}$ of new or refurbished U.S. PV manufacturing capacity is expected to come online in Q1 2019, and an additional $1.7 \mathrm{GW}$ is under construction.

- Historically, actual production capacity brought online has often taken longer and/or been lower than originally reported.

- An additional $600 \mathrm{MW}$ of U.S. PV manufacturing capacity expansion, which was announced, has not yet started construction. 


\section{State and Federal Updates}

\section{Global PV Deployment}

\section{U.S. PV Deployment}

\section{PV System Pricing}

\section{Global Manufacturing}

6 Component Pricing
- Global module and module-component prices have dropped $94 \%$ to $97 \%$ in the past 12 years, $53 \%$ to $77 \%$ in the past five years, and $39 \%$ to $53 \%$ in the last year.

- PVinsights reports that global PV module prices dropped from $\$ 0.31 / \mathrm{W}$ to $\$ 0.22 / \mathrm{W}$ in 2018. 


\section{PV Value Chain Spot Pricing Q1 2007-Q1 2019}

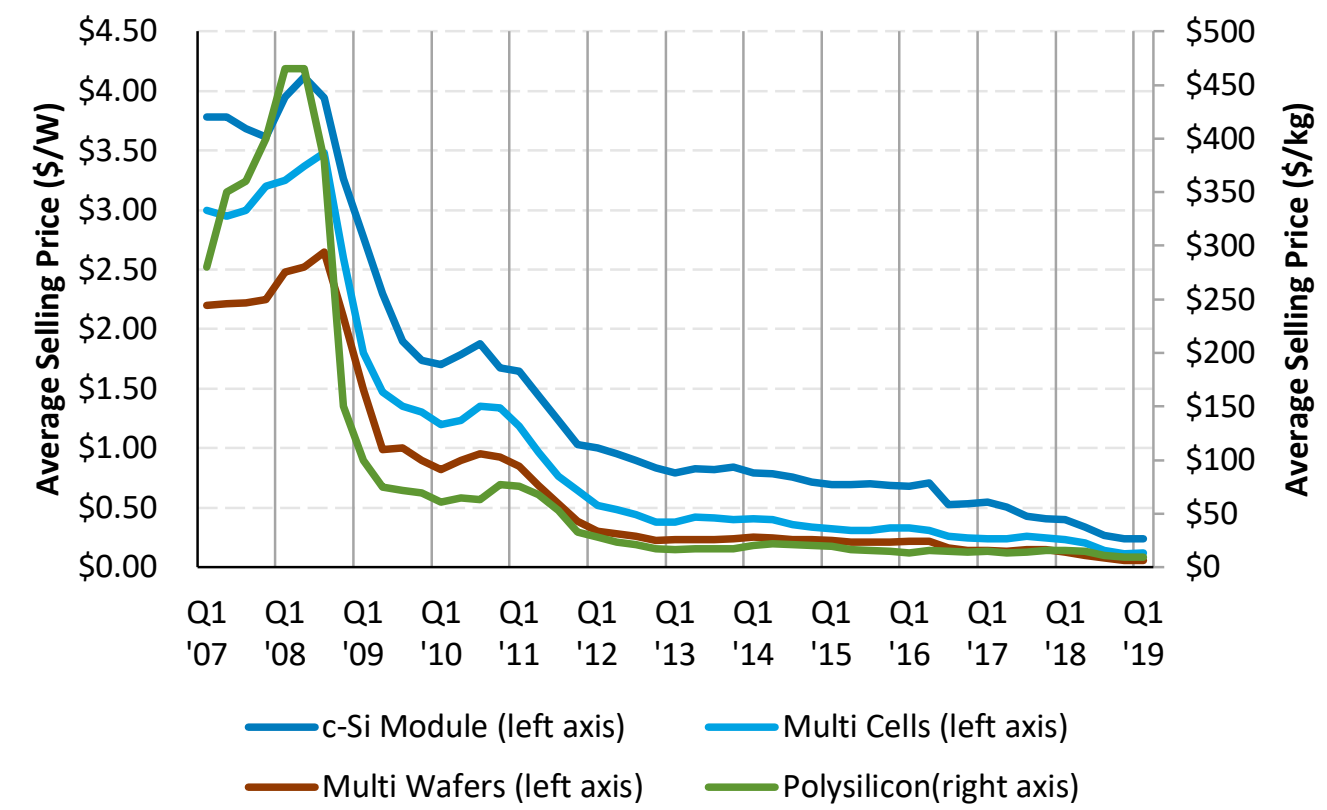

Global module and module-component prices have dropped $94 \%$ to $97 \%$ in the past 12 years, $53 \%$ to $77 \%$ in the past five years, and $39 \%$ to $53 \%$ in the last year. 


\section{PV Value Chain Spot Pricing, 2018}

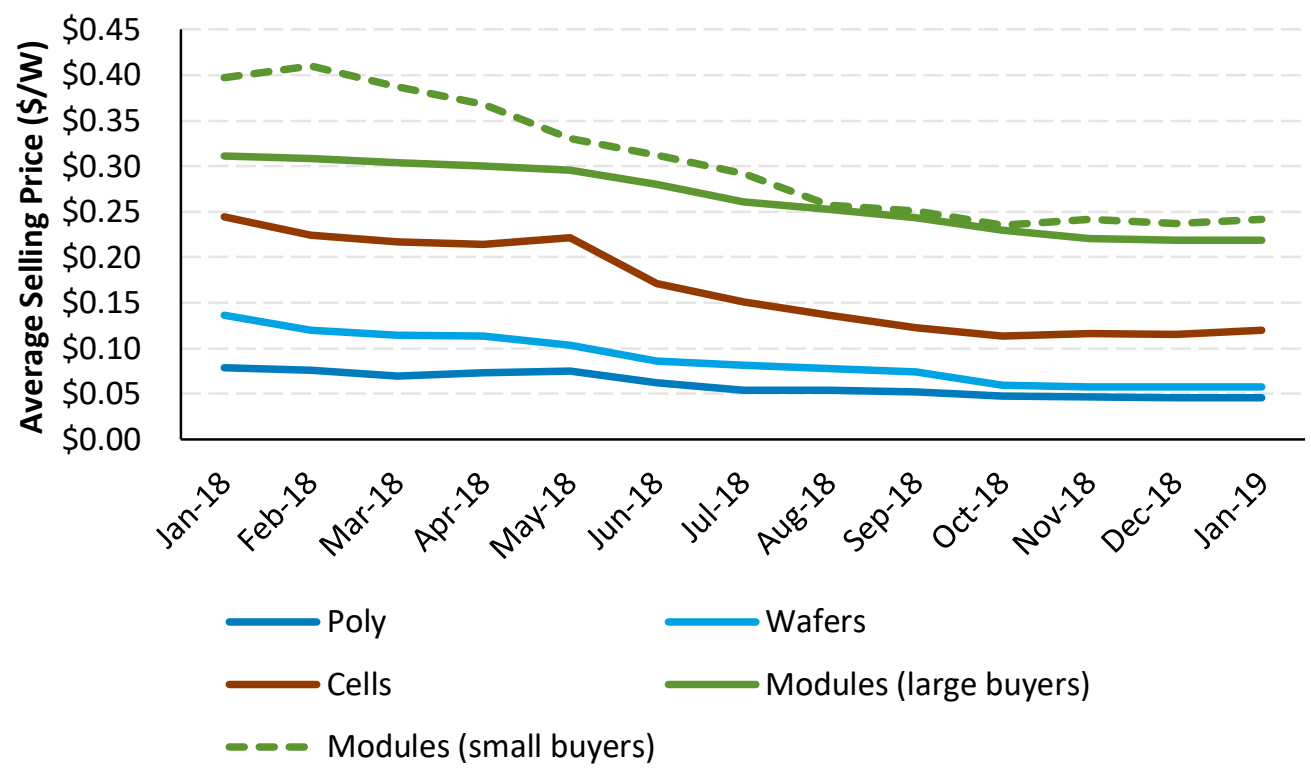

- While global module and modulecomponent prices dropped significantly in 2018, they were relatively flat in Q4.

- PVinsights reports that global PV module prices dropped from $\$ 0.31 / \mathrm{W}$ to $\$ 0.22 / \mathrm{W}$ in 2018.

- BNEF reports that, in 2018, cells dropped from $\$ 0.24 / \mathrm{W}$ to $\$ 0.12 / \mathrm{W}$, wafers dropped from $\$ 0.14 / \mathrm{W}$ to $\$ 0.06 / \mathrm{W}$, and polysilicon dropped from $\$ 16.6 / \mathrm{kg}$ to $\$ 9.6 / \mathrm{kg}$ (\$0.08/W to $\$ 0.05 / \mathrm{W})$. 


\section{Module Average Selling Price: Global versus United States}

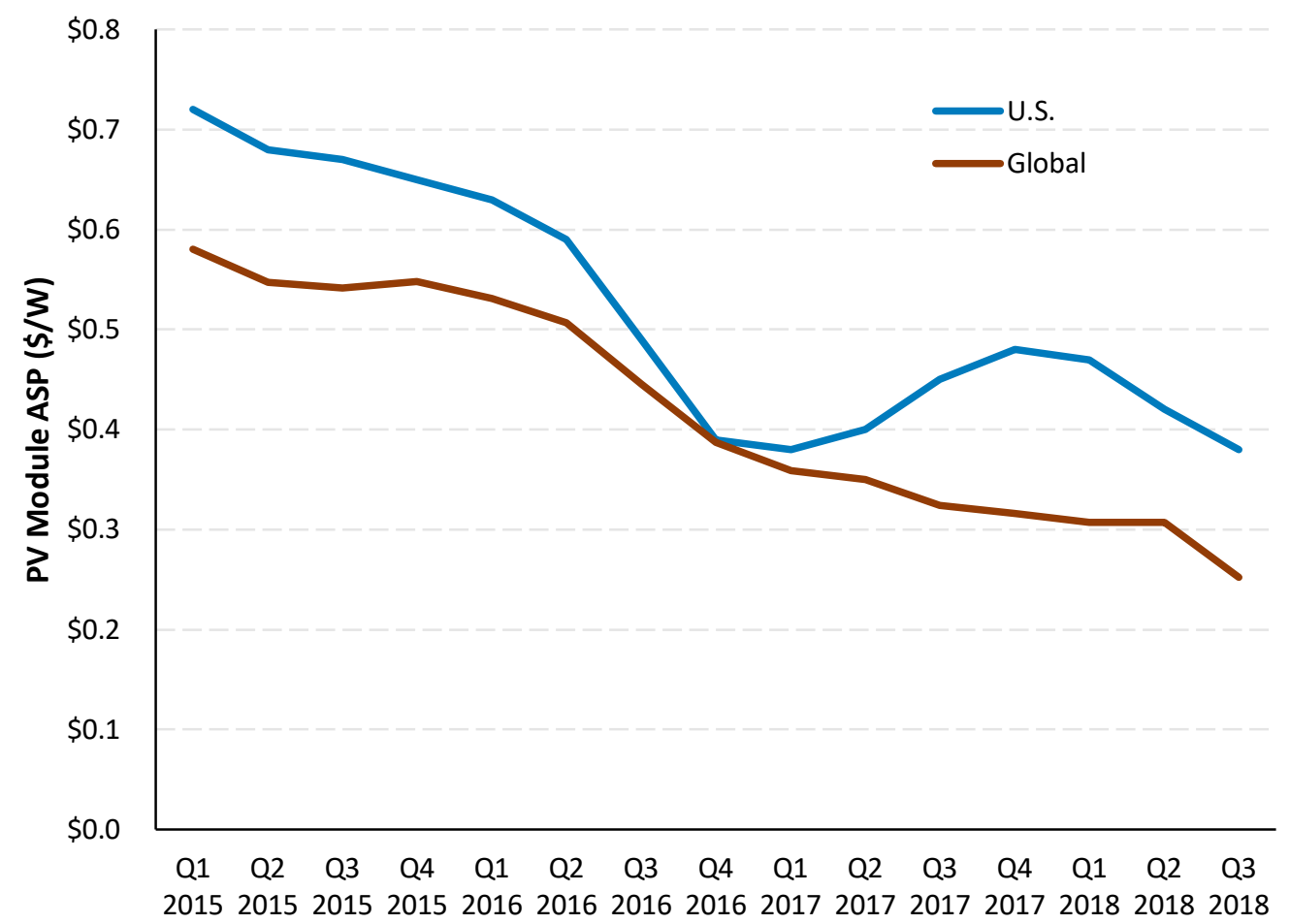

- In Q3 2018, U.S. module prices continued to fall, dropping to their lowest recorded levels, but they were still trading at a significant premium over global module ASP.

- Modules sold in the United States in Q3 2018 were 21\% lower in price than modules sold in the United States in Q4 2017 but $51 \%$ higher in price than the global average. 


\section{Inverter Pricing}

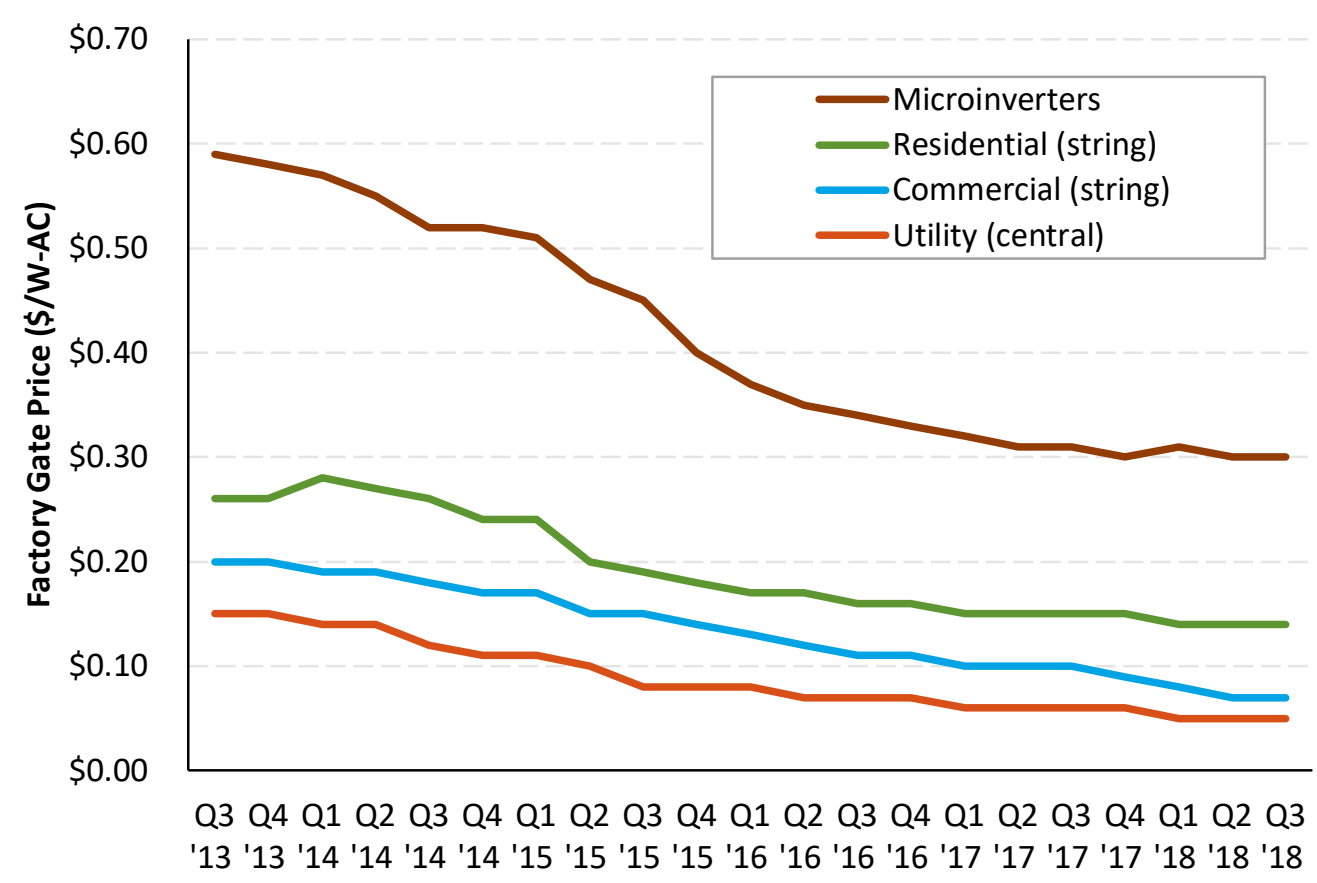

U.S. inverter pricing was relatively flat in Q3 2018, though it was still trading at historical lows. 


\section{State and Federal Updates}

\section{Global PV Deployment}

\section{U.S. PV Deployment}

\section{PV System Pricing}

\section{Global Manufacturing}

6 Component Pricing

7 Market Activity
- SREC pricing rose in virtually all markets in the second half of 2018, as some markets are in undersupply, and others have been buoyed by proposed or enacted legislation.

- At the end of October 2018, solar stocks were down $30 \%$ for the year, compared to $5 \%$ for the broader market.

- In 2018 , solar stocks were down $28 \%$ compared to $-1 \%$ performance by the S\&P 500 Index.

- 2018 global and U.S. solar investment were \$132B and $\$ 21 B$ respectively, the vast majority of which went to project deployment. 


\section{SREC Pricing}

- SREC pricing rose in all markets in the second half of 2018.

- Some of these markets are in undersupply, but many have been buoyed by proposed or enacted legislation, raising RPSs.

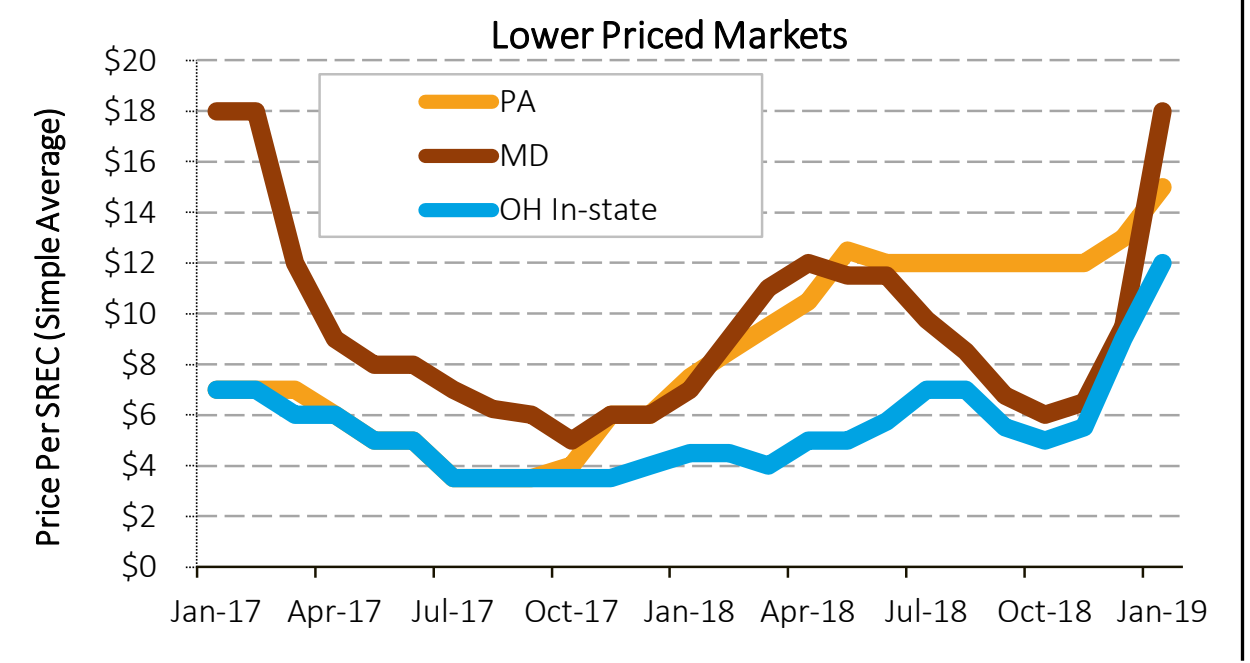

Sources: SRECTrade, https://www.srectrade.com/, accessed 10/25/18.
- In December 2018, Washington D.C. unanimously approved legislation mandating $100 \%$ renewable electricity by 2032.

- As of December 2018, a veto-proof majority of legislatures had pledged support for a Maryland bill doubling their RPS to $50 \%$ by 2030.

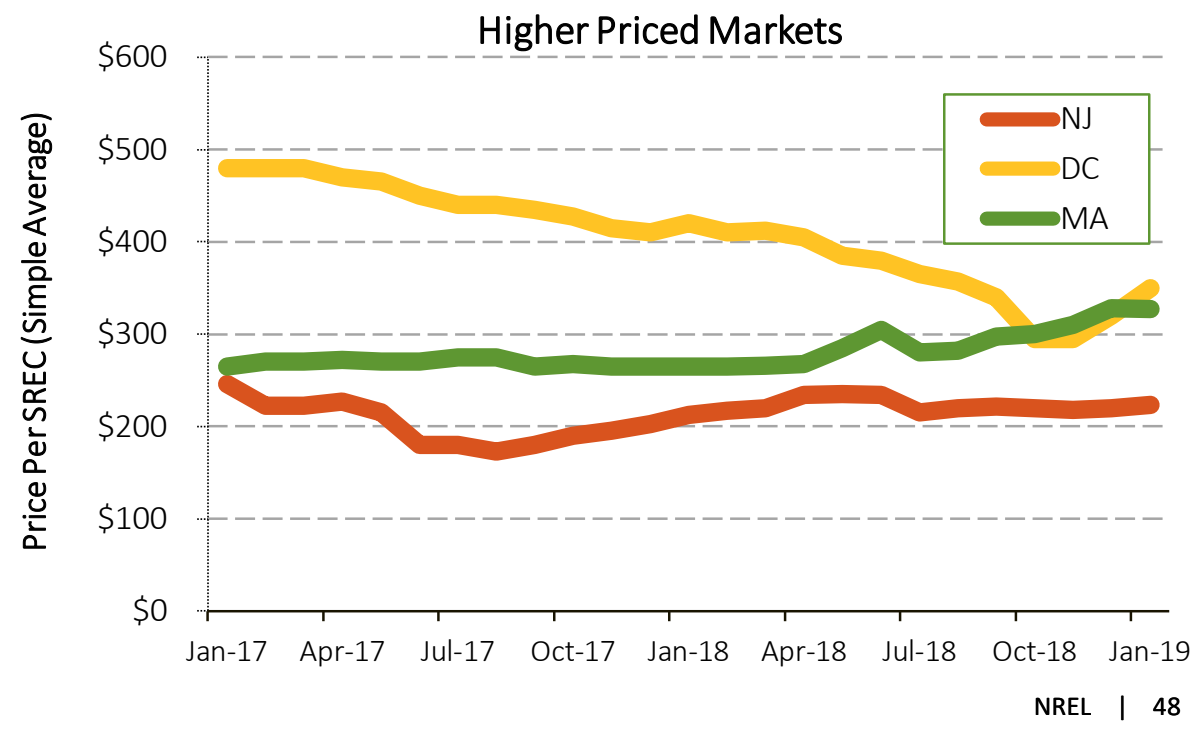




\section{Stock Market Activity}

- In 2018, many solar stock prices plummeted after the Chinese announcement in late May of a decrease in subsidies, causing an oversupply of PV modules and cells in the marketplace.

- In Q4 2018 and January of 2019, solar stocks followed the general marketplace, recovering $10 \%$ of their losses from December 24, 2018 to January 16, 2019.

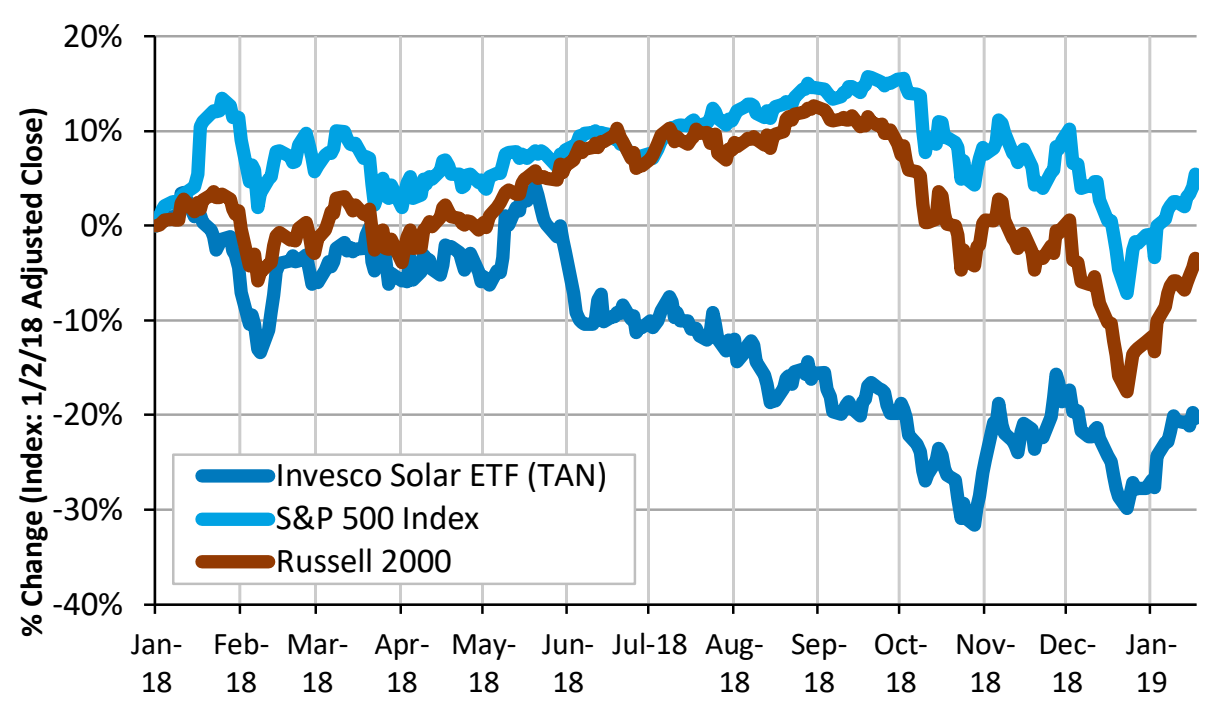

Source: Stock market: Yahoo Finance (01/19/19); Mercom (01/19/19).
- While most solar stocks performed poorly in 2018 , installers tended to perform better than manufacturers.

\section{Solar Stock Performance}

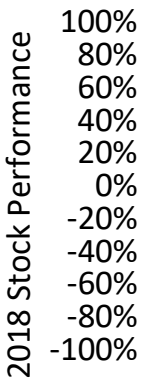

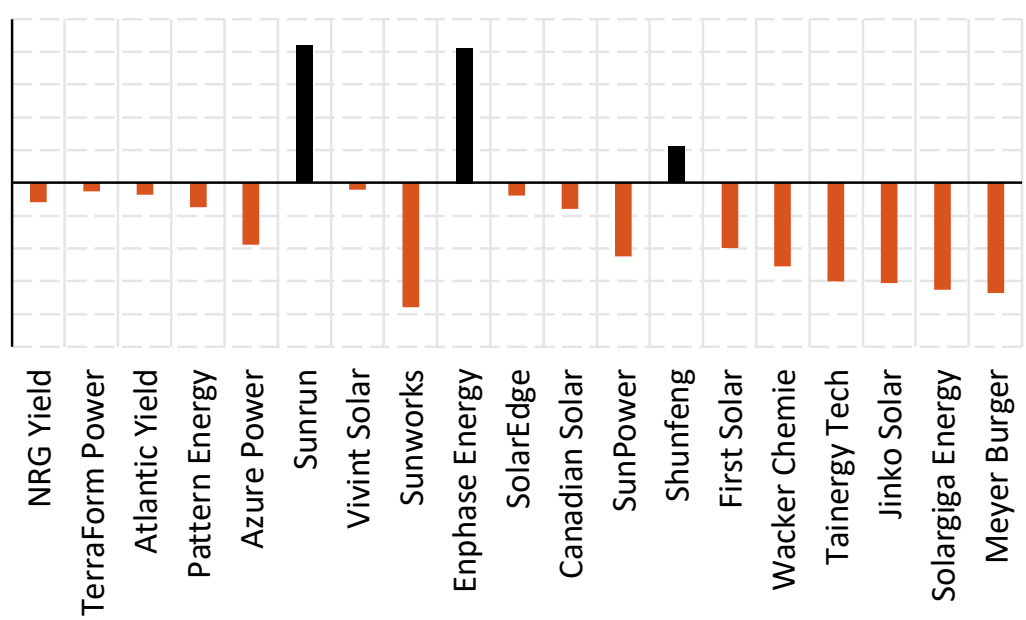

NREL | 49 


\section{Global Solar Investments}

- In 2018, non-project global solar public market investments grew 35\% y/y but were still well below 2013-2015 levels.

- In 2018, global VC\&PE investments in solar approached their lowest levels since 2006.

- The largest solar public market deal in 2018 was a \$808MM IPO of the French PV developer Neoen SA.

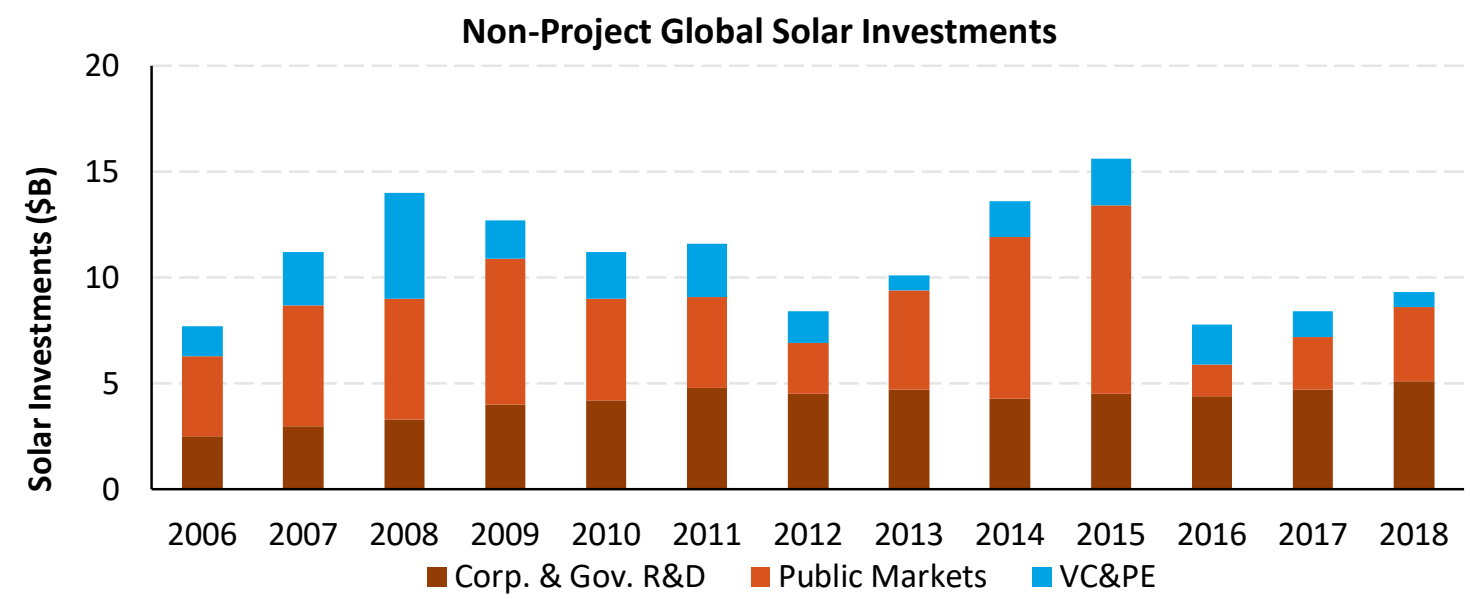

2018 Global Solar Investments (\$132B)

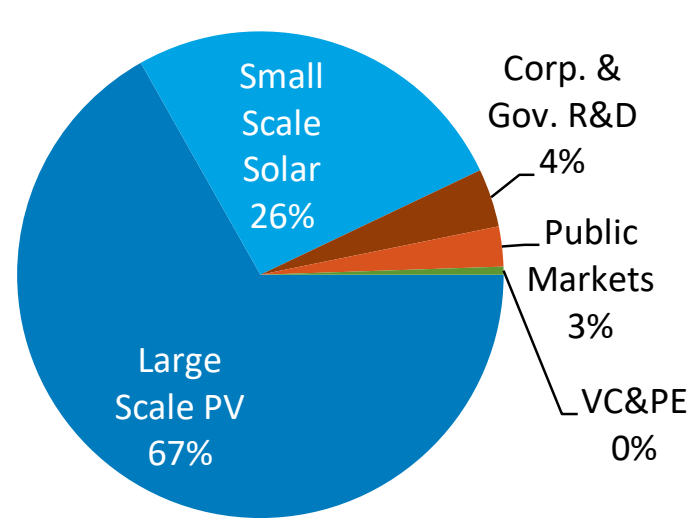




\section{U.S. Solar Investments}

- U.S. public markets in 2013-2015 raised funds for yieldcos (e.g., Terraform and 8point3) and third-party residential companies (e.g., SolarCity, SunPower)-but dropped precipitously in 2016.

- The largest U.S. solar deal in 2018, was the $\$ 650 \mathrm{MM}$ in a Private Investment in Public Equity transaction by TerraForm.

- Most other public market raises were significantly smaller.

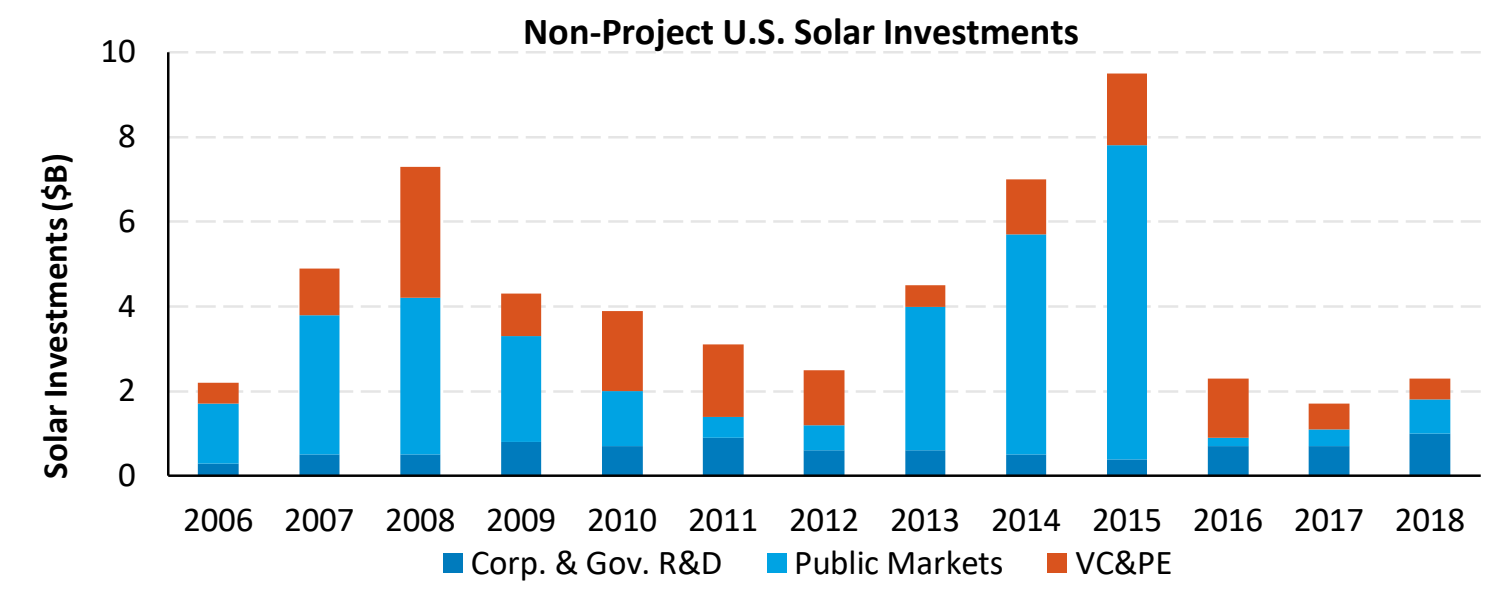

- In December 2018, the CEO and founder of 8 minuteenergy, a utility-scale development company, completed the sale of his $50 \%$ stake in the company to his cofounder for $\$ 200 \mathrm{MM}$.

- Total U.S investments in solar energy remained relatively flat, $y / y$, at approximately \$21B.

- The majority of U.S. investment in solar has historically gone to funding of projects-90\% in 2018.

\section{U.S. Solar Investments (\$21B)}

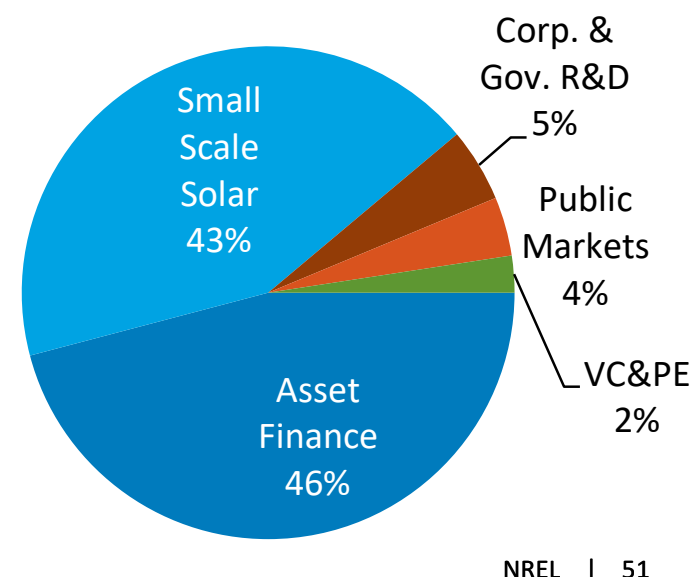




\title{
Thank You
}

\author{
www.nrel.gov
}

NREL/PR-6A20-73234

Special thanks to Dan Bilello, Wesley Cole, Jeff Logan, Mike Meshek, Eric O'Shaughnessy, Ashwin Ramdas, and Brittany Smith. 


\section{List of Acronyms and Abbreviations}

$\begin{array}{lll}\text { - } & \mathrm{AC} & \text { alternating current } \\ \text { - } & \mathrm{ASP} & \text { average selling price } \\ \text { - } \mathrm{BNEF} & \text { billion } \\ \text { - } \mathrm{CSP} & \text { Bloomberg New Energy Finance } \\ \text { - } \mathrm{DC} & \text { concentrating solar power } \\ \text { - } \mathrm{EIA} & \text { U.S. Energy Information Administration } \\ \text { - } \mathrm{ETF} & \text { exchange traded fund } \\ \text { - } \mathrm{GW} & \text { gigawatt } \\ \text { - } \mathrm{GW}-\mathrm{th} & \text { gigawatt-thermal } \\ \text { - } \mathrm{IOU} & \text { investor-owned utility } \\ \text { - } \mathrm{IPO} & \text { initial public offering } \\ \text { - } \mathrm{ISO} & \text { independent system operator } \\ \text { - } \mathrm{kg} & \text { kilogram } \\ \text { - } \mathrm{kW} & \text { kilowatt } \\ \text { - } \mathrm{LCOE} & \text { levelized cost of energy } \\ \text { - } \mathrm{LMI} & \text { low and moderate income } \\ \text { - } \mathrm{m} & \text { meter-squared } \\ \text { - } \mathrm{MLPE} & \text { module-level power electronics } \\ \text { - } \mathrm{MM} & \text { million } \\ \text { - } \mathrm{MW} & \text { megawatt } \\ \text { - } \mathrm{MWh} & \text { megawatt-hour }\end{array}$

- NEM

- O\&M

- PPA

- PV

- R\&D

- $\mathrm{Q}$

- REC

- RPS

- S\&P

- SEIA

- SETO

- SREC

- tan

- TPO

- TWh

- UPV

- VC\&PE

- $\mathrm{W}$

- $y / y$

- YTD net energy metering

operations and maintenance power purchase agreement

photovoltaic

research and development

quarter

renewable energy certificate

renewable portfolio standards

Standard and Poor's

Solar Energy Industries Association

Department of Energy Solar Technology Office

solar renewable energy certificate

Invesco Solar ETF

third-party owner

terawatt-hour

utility-scale PV

venture capital and private equity

watt

year over year

year to date 